\title{
Lateglacial/Holocene environmental changes in the Mediterranean Alps inferred from lacustrine sediments
}

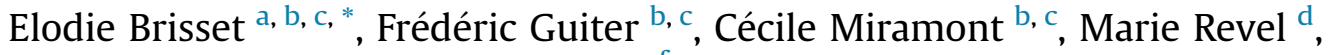 \\ Edward J. Anthony ${ }^{\mathrm{a}, \mathrm{e}}{ }^{\text {, }}$, Claire Delhon ${ }^{\mathrm{f}}$, Fabien Arnaud ${ }^{\mathrm{g}}$, Emmanuel Malet ${ }^{\mathrm{g}}$, \\ Jacques-Louis de Beaulieu ${ }^{\text {b }}$
}

a Aix-Marseille Université, CNRS, IRD, Collège de France, UM 34 CEREGE, Europôle Méditerranéen de l'Arbois, BP 80, 13545 Aix-en-Provence Cedex 4, France
b Aix-Marseille Université, CNRS, UMR 7263 IMBE, Europôle Méditerranéen de l'Arbois, BP 80, 13545 Aix-en-Provence Cedex 4, France
' ECCOREV Research Federation, Europôle Méditerranéen de l'Arbois, BP 80, 13545 Aix-en-Provence Cedex 4, France
d Université Nice Sophia Antipolis, CNRS, UMR 7329 GEOAZUR, 250 rue A. Einstein, 06560 Valbonne-Sophia Antipolis, France
e Institut Universitaire de France, France
${ }^{\mathrm{f}}$ Université Nice Sophia Antipolis, CNRS, UMR 7264 CEPAM, Campus Saint-Jean-d'Angély, SJA3, 24 Avenue des Diables Bleus, 06357 Nice Cedex 4, France
${ }^{\mathrm{g}}$ Université de Savoie, CNRS, UMR 5204 EDYTEM, Pôle Montagne Campus scientifique, 73376 le-Bourget-du-Lac Cedex, France

Keywords:

Cirque glaciers

Lateglacial

Pollen biostratigraphy

Holocene climatic optimum

Mediterranean Alps

Lake sediment

${ }^{14} \mathrm{C}$ ages

\section{A B S T R A C T}

This study investigates sediment cores from the Mediterranean alpine lakes located in upvalley cirques upper than 1700 metres a.s.l. using sedimentological, palynological and geomorphological studies, in order to document environmental changes following the last phase of glacier retreat. These results are considered in the framework of the deglaciation characterized from 16 sediment cores from highaltitude lakes and mires including $104{ }^{14} \mathrm{C}$ ages and geomorphological studies of the Mediterranean Alps. Considering each sediment core proxy as an independent observation, i.e., comparisons between ${ }^{14} \mathrm{C}$ ages and palynostratigraphy, between ${ }^{14} \mathrm{C}$ ages and lithostratigraphy, between palynostratigraphy and lithostratigraphy, these data are aimed at contributing to a better understanding of the timing of postglacial environmental changes. The ${ }^{14} \mathrm{C}$ ages combined with pollen biostratigraphy indicate that the deglaciation of cirque catchments is dated between 14,500 and 13,000 cal. BP, i.e., during the Lateglacial Interstadial (Greenland Interstadial-1e). The sixteen lacustrine and mire sediment records are systematically characterized by three units from bottom to top: organic-poor blue clay, beige to light-brown silty clay and organic rich dark brown gyttja lithotype. During the Younger Dryas, lakes located below $2300 \mathrm{~m}$ a.s.l. were ice-free and their pollen record indicates steppe conditions. The sedimentary facies also informs on the timing of glacial-dominated processes. The onset of organic-rich gyttja is dated at 11,000 cal. BP suggesting the last influence of cirque glaciers in these lakes at the beginning of the Holocene. The timing of the onset of this organic rich unit differs in sites ( \pm 2000 years) probably due to an altitudinal and exposure gradient of the glacial cirques. The presence of gyttja from 11,000 cal. BP to Present indicates biogenic infilling lake for all the Holocene. Even though the literature have indicated rock glacier advances occurred during the Holocene (Subboreal and LIA) in the south of the Alps, no significant sedimentological patterns related to glacier fluctuations are recorded in Lake Vens. The glacier fluctuations in the Mediterranean Alps are concomitant with those dated in the non-Mediterranean Alps, thus suggesting a main common climate forcing. However, the increase in terrigenous sediment inputs since $1800 \mathrm{cal}$. BP is mainly due to human activities.
\end{abstract}

\section{Introduction}

Significant advances have been made over the last few decades in understanding the chronology of alpine glacier retreat and associated Holocene palaeoenvironmental changes. The transition between the Last Glacial Maximum (LGM) and the Holocene is a

\footnotetext{
* Corresponding author. Aix-Marseille Université, IMBE, Europôle Méditerranéen de l'Arbois, BP 80, 13545 Aix-en-Provence Cedex 4, France.

E-mail address: elodie.brisset@gmail.com (E. Brisset).
} 
key time interval that provides contrasting boundary conditions for terrestrial ecosystems response with episodes of insolation changes and ice melting. At the end of the Pleistocene and consecutively to alpine glacier retreat, new ecosystems (soil, vegetation, and fauna) developed on freshly ice-free valleys; profoundly modifying mountain landscapes (e.g., Tinner et al., 1996; Heiri et al., 2003; Lotter and Birks, 2003). However, the timing of these changes (e.g., synchronism, delay) is poorly known, notwithstanding the fact that they are crucial to a better understanding of thresholds in the Earth's climatic system (Alley et al., 2003). This is especially true in the southernmost part of the Alpine range, especially the Mediterranean Alps, since there is a lack of in situ landform dating and a dispersed corpus of lake sediment studies. The Mediterranean Alps are a privileged environment for investigating landscape and climate change since the Postglacial because: (1) strong altitude (several summits attain $3000 \mathrm{~m}$ a.s.l.), climate and ecotone gradients amplify responses to climate change and, (2) the proximity of the Mediterranean Sea (less than $30 \mathrm{~km}$ ) provides a good context for studying the effects of European and Mediterranean climatic influences.

In this context, lake sediment sequences have been studied to constrain the trends and the timing of glacier retreat and the subsequent Deglacial and Holocene. Since the pioneer studies of de Beaulieu (1977), very few sediment cores from the Mediterranean Alps concerning the last 20,000 years (Lotter and Birks, 2003) have been studied. Most of the well-preserved long-term archives are high-altitude lakes and mires sediments in inherited glacial cirques located behind glacial steps. Most studies of postglacial sediments in the Mediterranean Alps combine three independent analyses: (1) sedimentological descriptions, (2) palynological analysis and (3) radiocarbon dating, providing a biostratigraphical framework used to constraint periods of cirque glacier activity. Due to the lack of terrestrial macroremains in these high-elevation environments, one of the main issues is dating the early stages of deglaciation: inconsistencies in some radiocarbon age sets require a re-evaluation of the radiocarbon framework (Pallàs et al., 2006). Palynology is a powerful tool for Quaternary chronostratigraphy. The richness of palynological studies in the Alps provides a well-documented and well-constrained biostratigraphical framework based on plant taxa expression into pollen diagrams and vegetation changes (Van der Knaap et al., 2005). Thus, the palynostratigraphical framework can support radiocarbon dating of glacial features and of lacustrine sediments to reconstruct the chronological framework of postglacial environmental changes over the Mediterranean Alps.

In this study, we use a multi-proxy approach involving sedimentological and palynological analysis, as well as ${ }^{14} \mathrm{C}$ dating, to document environmental changes starting from the early phases of lake development and infilling through to glacier retreat from the Lateglacial to the Holocene period. We first conduct a synthesis of 15 published and unpublished studies of high-altitude lake and mire sediment records, and then follow up with the sedimentological and palynological analysis of a sediment record of Lake Vens (2330 $\mathrm{m}$ a.s.l.) located in the French Maritime Alps. On the basis of comparisons between: (1) ${ }^{14} \mathrm{C}$ ages and palynostratigraphy, (2) ${ }^{14} \mathrm{C}$ ages and lithostratigraphy, and (3) palynostratigraphy and lithostratigraphy, these new results throw further light on existing climatic datasets of this region. These three approaches provide interesting perspectives to investigate postglacial environmental changes in the region. The aims are: (1) to review the glacial and deglacial geomorphological evolution in the Mediterranean Alps, (2) to reconstruct phases of the palaeoenvironmental variability at Lake Vens and to establish a chronology for the sediment core using a combination of radiocarbon ages and palynostratigraphy and (3) to interpret these new results in the framework of the deglaciation chronology at the scale of the Alps.

\section{The Mediterranean Alps}

The study area is located between latitudes $44.4^{\circ} \mathrm{N}$ and $44.0^{\circ} \mathrm{N}$ and lies astride mountain cirque catchments of the Southern Alps (Fig. 1): the Upper Eastern Durance (UED) and the French and Italian Maritime Alps (FMA and IMA). The mean altitude is about $2000 \mathrm{~m}$ a.s.l. and the highest peaks reach elevations of $3000 \mathrm{~m}$ a.s.l. The UED is drained by the Durance, Ubaye and Verdon Rivers. The Maritime Alps are drained by the Var, Tinée, Vésubie and Roya Rivers on the French side and by the Gesso and Stura di Demonte Rivers in the Italian side (Fig. 1).

Due to the short source-to-sink distance, sharp topographic contrasts provide favourable conditions for steep-side cutting, narrow valleys and canyon development. The relief can be summarized in a two-step topographic profile: dissected mountains crests are characterized by vertical rock bars overhanging small smoothed glacial cirques, which in turn overhang their main fluvial valleys by steep slopes of $25^{\circ}-45^{\circ}$. The geology of the Maritime Alps massif consists mainly of granitic basement rocks and Permian sandstones. Vast areas of sedimentary rocks, composed of conglomerates and evaporites, occur on the southern and western flanks of the massif. In the UED, the lithology consists of sedimentary terrains forming the limestones of the Ubaye-Embrunais thrust-sheets and Cretaceous flysch, Aptian-Albian black shales, Upper Cretaceous limestones, and Annot sandstones. Quaternary deposits consist in alluvial deposits and slope colluviums between 1000 and $2000 \mathrm{~m}$ a.s.l. As a result of the steepness and sediment cover of these slopes, numerous landslides have occurred on the flanks of the main valleys (Julian and Anthony, 1996).

The vegetation consists of Mediterranean plants tolerant to altitude and plants having affinity with a cool and humid climate. The intra-alpine low-altitude vegetation belt (500-800 $\mathrm{m}$ a.s.l.) is dominated by a diversified oak forest (mainly pubescent oak). Cultivated trees such as chestnut and olive trees are common on south-exposed slopes of the intra-alpine valleys. The mountain vegetation belt (800-1500 $\mathrm{m}$ a.s.l.) exhibits a strong asymmetry in conifer forest between the southern and the northern slopes. Scot pines dominate drier southern slopes whereas wetter northern slopes are favourable to the development of fir-spruce forests regularly associated with beech trees. Vegetation in cirque valleys is characteristic of the sub-alpine belt (1500-2200 m a.s.l.). Larch trees are sparsely distributed on slopes. This more open landscape is dominated by dwarf species such as juniper, blueberry shrubs and rhododendron. The upper limits of forest attain $2200 \mathrm{~m}$ on the northern slopes and $1900 \mathrm{~m}$ on the southern slopes. Beyond $2200 \mathrm{~m}$ a.s.l., the alpine vegetation belt is dominated by the herbaceous species of alpine meadows.

A major aspect of the climate of this alpine mountain setting is the influence of the Mediterranean. At $1800 \mathrm{~m}$ a.s.l., the climatic regime is typical of the northern Mediterranean (dry summers and mild winters) and influenced by altitudinal gradients. In both the FMA, the IMA as in the UED, air temperatures are generally higher than in the northern Alps and snow cover duration is shorter. The mean annual air temperature at $1800 \mathrm{~m}$ a.s.l. is $5^{\circ} \mathrm{C}$, varying from $0.3^{\circ} \mathrm{C}$ in winter to $9.9^{\circ} \mathrm{C}$ in summer (Durand et al., 2009). The study area shows relatively high mean snow thickness values at all altitudes due to rather high amounts of moisture from the nearby Mediterranean Sea (Durand et al., 2009). Snow cover duration in the study area is 140 days at $1800 \mathrm{~m}$ a.s.l. and 185 days at $2100 \mathrm{~m}$ a.s.l. A strong precipitation regime characterised by a NW-SE asymmetry differentiates the Maritime Alps and the UED in terms of climatic domains. The FMA and the IMA are characterized by higher mean annual precipitation $(1340 \mathrm{~mm})$ than the UED $(1200 \mathrm{~mm})$. The contrast in precipitation regime is stronger during summer when precipitation occurs as rainfall. The southeast flanks 


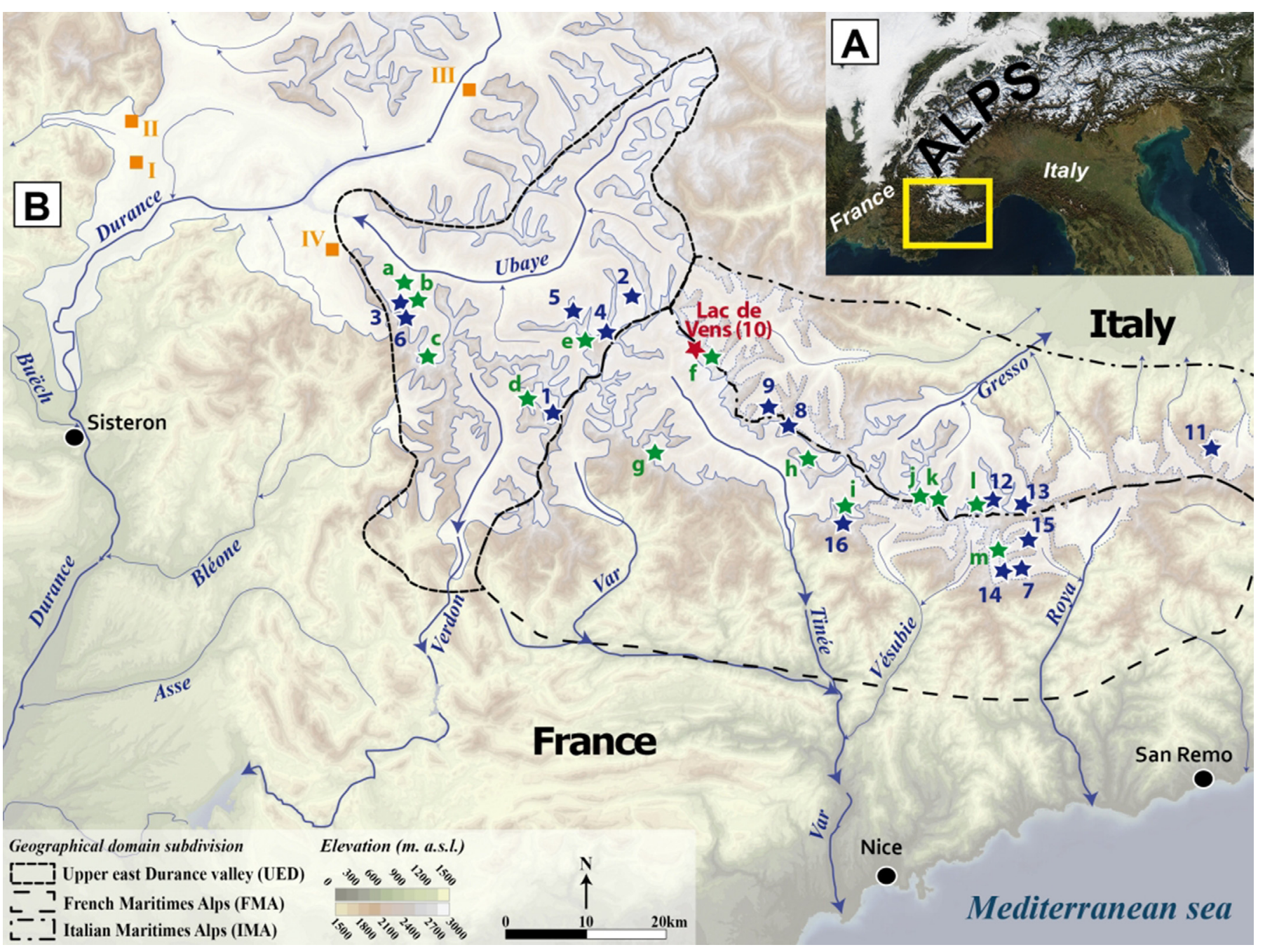

Fig. 1. (A) Location of the Mediterranean Alps; (B) Regional map of the Mediterranean Alps and geographical domain subdivisions (black dashed lines). Blue stars indicate lakes and mires of the core sediment corpus (1-Allos, 2-Lauzanier, 3-Vallon du Loup, 4-Restefond, 5-Terres Plaines, 6-Vallon de Provence, 7-Long Inférieur, 8-Orgials, 9-Fate, 10-Vens, 11-Rifugo Mondovi, 12-Vei del Bouc, 13-Sabion, 14-Mouton, 15-Grenouilles, 16-Petit). Geomorphologically mapped glacial stages in upper cirque valleys are indicated by green stars (aDormillouse, b-Ambouin, c-Haut-Laverq, d-Allos, e-Restefond, f-Vens, g-Roya, h-Saint-Sauveur, i-Mollières, j-Gelas Peak Northeast face, k-Gelas Peak Northwest face, l-Upper Gresso, m-valley of Marvels and Bego peak). The maximum extension of the Last Glacial glacier tongue is shown in transparent shade delimited by a continuous line where such extension is ascertained and by a dashed line for uncertain limits. Other sites cited in text are indicated by orange squares (I- Pelléautier; II- Corréo; III- Siguret; IV-Saint-Léger). (For interpretation of the references to colour in this figure legend, the reader is referred to the web version of this article.)

of the Maritime Alps, along the Italian border, act as an atmospheric barrier resulting in exposure of the southernmost massif to Mediterranean air masses while sheltering it from north Atlantic winds. In contrast to the Maritime Alps, the UED is mostly exposed to active weather systems associated with northwest air masses.

\section{Overview of the glacial and deglacial geomorphological evolution in the Mediterranean Alps}

\subsection{The valley glacier phase}

Several geomorphological studies of the Quaternary glaciation of the lowlands of the southwestern Alps have been published. Two main glacial stages are recognized in the Durance valley tributaries (Gidon and Monjuvent, 1969; Jorda, 1975; Tiercelin, 1977; Julian, 1980; Jorda and Rosique, 1994; Jorda et al., 2000; Rosique, 2004). The oldest stage is attributed to the MIS- 6 (Riss) on the basis of altitude and degree of soil weathering. Jorda et al. (2000) attributed the freshest and more extensive glacier forms entrenched in these former glacial deposits to the Last Glacial Maximum (LGM, MIS-2,
Würm). At their maximal extension, glacier tongues advanced $120 \mathrm{~km}$ into the Durance valley (500 m a.s.l.), $35 \mathrm{~km}$ into the Verdon (1010 $\mathrm{m}$ a.s.l.), and $40 \mathrm{~km}$ into the Tinée (ca $500 \mathrm{~m}$ a.s.l.). This maximal extension is not directly dated and the authors have assumed that it could be related to the marine Heinrich-3 event (GS-3: 27,500-23,300 years; Blockley et al., 2012). A phase of palaeosoil development (brown Mediterranean soil containing malaco-fauna typical of hygrophilous woodlands) dated at $2 \sigma$ in the Bléone valley at 29,900-22,900 cal. BP (Jorda, 1988) and in the Buëch valley at 24,000-22,400 cal. BP (Brugal, 1991 in Rosique, 2004) indicates river incision and reduced detrital sediment supply that argue in favour of the establishment of interstadial climatic conditions (termed the "Bléone Neowürmian Interstadial"). The latest glacier extension corresponding to the near-maximum extent in the Durance is well ${ }^{14} \mathrm{C}$ dated from subfossil wood buried in glacial till at $23,000-20,800 \mathrm{cal}$. $\mathrm{BP}(2 \sigma)$, which is concomitant with the marine Heinrich-2 event (Jorda et al., 2000; Rosique, 2004).

The last glacier retreat in the Durance valley has been depicted as a rapid phenomenon by Jorda and Rosique (1994) and Rosique (2004) on the basis of palynological interpretations of valley 

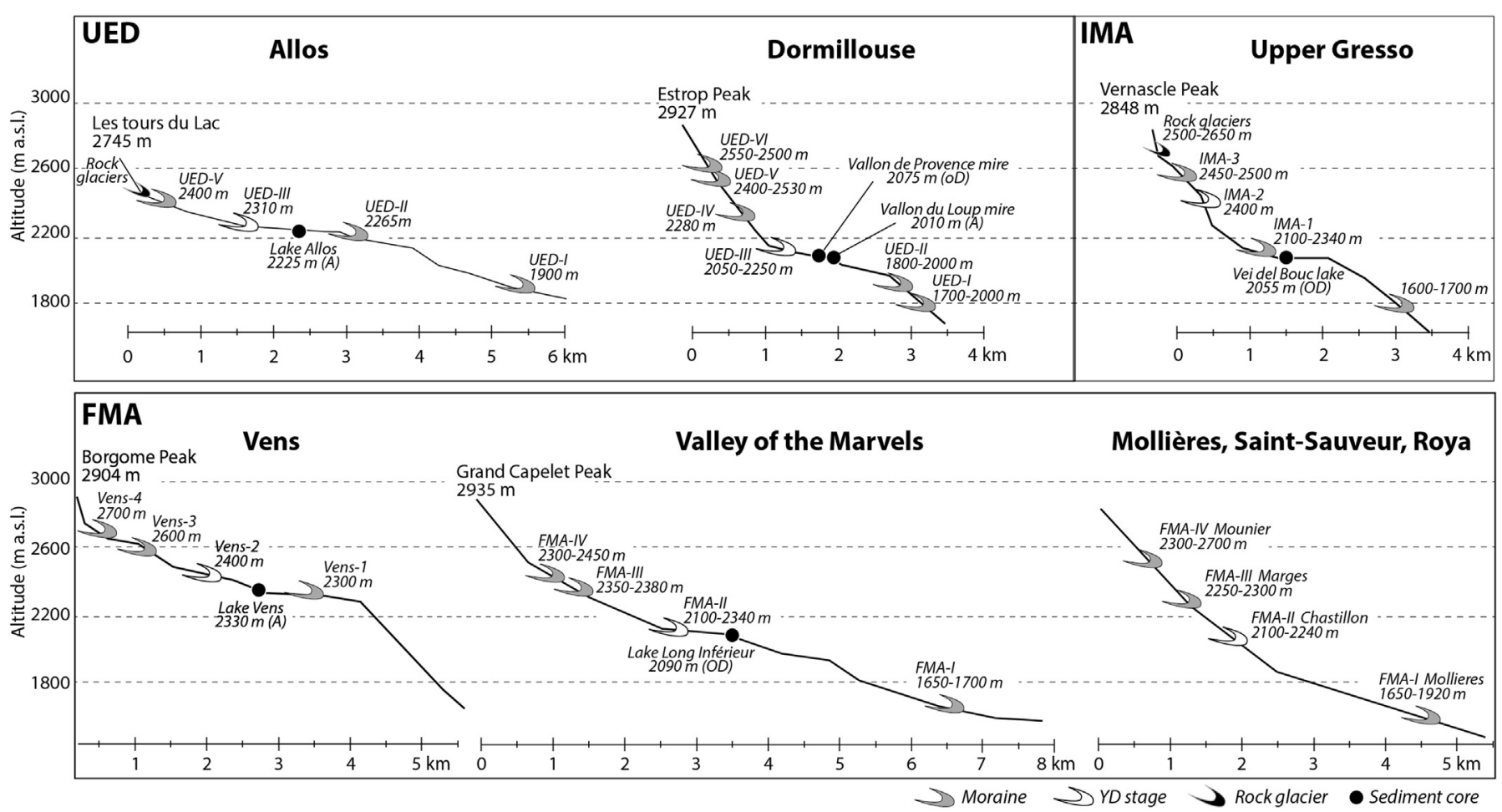

Fig. 2. Cirque valley profiles showing altitudinal locations of moraine ridges (from stage I to stage VI) and sediment cores from the Upper Eastern Durance (UED), the Italian Maritime Alps (IMA) and the French Maritime Alps (FMA). The Younger Dryas moraine stage is shown in white. In brackets are indicated the oldest palyno-stratigraphical zone in the pollen diagram of each sediment core (OD: Oldest Dryas; oD: Older Dryas; A: Alleröd).

glacio-lacustrine sequences The postglacial infilling of the valley started at the beginning of the Oldest Dryas chronozone (GS-2b, Blockley et al., 2012) between 23,000 and 20,000 cal. BP [e.g., the mires of Pelléautier, Siguret, Roche de Rame, the Lauzes passes (De Beaulieu, 1977) and Corréo (Nakagawa, 1998)].

Evidence of Quaternary glaciation in the Maritime Alps (Tinée, Vésubie and Roya valleys) is scarcer, probably due to intense erosion leading to deeply incised valleys (Dubar and Anthony, 1995). The LGM is poorly constrained spatially on the French side of the Alps. In the Tinée valley, the glacier front at its maximum extent is located at $500 \mathrm{~m}$ a.s.l. (Julian, 1980). Further upstream in the upper Tinée valley, Bigot-Cormier et al. (2005) have indirectly constrained the age of the deglaciated valley by ${ }^{10} \mathrm{Be}$ dating of slopes located at $1600 \mathrm{~m}$ a.s.l. at $18,217 \pm 4328$ years. Terminal moraines are better preserved on the Italian side of the Maritime Alps. Federici et al. (2012) provide ${ }^{10} \mathrm{Be}$ dating from the frontal moraine system that shows maximum glacier extension $(700 \mathrm{~m}$ a.s.l.) in the Gesso valley ranging from $20,140 \pm 1080$ to $22,110 \pm 1190$ years. This age is similar to the near LGM of the Durance valley. After this period, glacier tongues moved upstream, occupying small feeder glacial basins.

\subsection{The cirque glacier phase}

Numerous moraine ridges are located in catchments at altitudes ranging from 1700 to $2700 \mathrm{~m}$ a.s.l. Recessional moraines are found at high altitudes or above the knick point of glacial steps, which correspond to cirque disconnection from the main glacier tributary system. The altitudinal distribution of these end-moraines indicates short glacier advances during a general deglaciation trend (Fig. 2). These moraine ridges are unevenly distributed in catchments and most of the clearly distinguishable moraines are located in the Ubaye and Verdon valleys for the UED, i.e., in the Haut-
Laverq, Dormillouse, Ambouin, Restefond and Allos areas (Jorda, 1975, 1976, 1980, 1983; Jorda and de Beaulieu, 1977; Dijkstra et al., 1990; Brisset et al., 2014), in the upper Gesso valley (Hannss, 1970; Finsinger and Ribolini, 2001; Federici et al., 2003, 2008, 2012) for the ITM, and in the Mollières, Saint Sauveur and Roya valleys (Schweizer, 1968a, 1968b; Julian, 1980) as well as the valley of Marvels (Dubar and Poizat, 1976; Begin, 1990) for the FMA. They are characterised by elevations of moraine ridges corresponding to the Equilibrium Line Altitude (ELA in metres a.s.l.) calculated with the Höfer method (Höfer, 1922) and the corresponding ELA depression ( $\delta$ ELA) with respect to the present-day value (2800-2900 $\mathrm{m}$ a.s.l.). These data are summarised in Table 1.

The deglaciation time frame in the UED is constrained by Jorda (1975, 1980, 1983), Jorda and Beaulieu (1977), Jorda and Rosique (1994), Dijkstra et al. (1990) and Brisset et al. (2014) on the basis of pollen analysis and ${ }^{14} \mathrm{C}$ ages obtained in high altitude lakes and mires of Terres Plaines, Vallon de Provence, Vallon du Loup, Restefond, and Allos. Six glacial stages occupy cirques (Fig. 2). Stages UED-I (1700-2000 m a.s.l.) and UED-II (1800-2000 m) are characterized by poorly preserved moraine ridges (sandstone boulders and striated pebbles), correspond respectively to ELA at 2100 and $2200-2300 \mathrm{~m}$ a.s.l. ( $\delta$ ELA at $800 \mathrm{~m}$ and $600-700 \mathrm{~m}$ ), and are older than the early Alleröd. The lakes and mires of Restefond (Dijkstra et al., 1990), Terres Plaines, Vallon de Provence (Jorda and Beaulieu, 1977), and Allos (Brisset et al., 2014), all situated above these stages, provide pollen records starting at the beginning of the Alleröd, with a ${ }^{14} \mathrm{C}$ age of $13,600-13,070 \mathrm{cal}$. BP $(2 \sigma)$ in the Vallon de Provence mire and the onset of sedimentation in Allos Lake starting at $12,300 \mathrm{cal}$. BP. Therefore, authors attribute stages UED-I and II to the Oldest Dryas chronozone. Stage UED-III (2050-2200 m a.s.l., ELA at $2250-2400 \mathrm{~m}, \delta E L A: 600 \mathrm{~m}$ ), characterised by wellpreserved moraine ridges of sandstone boulders, is attributed to the most intense cooling of the Postglacial period i.e., the Younger 


\section{Table 1}

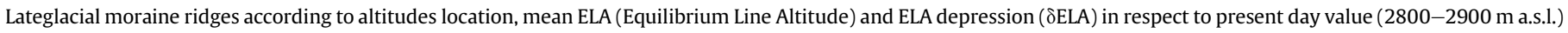

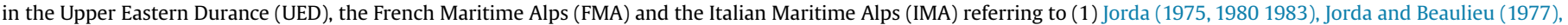

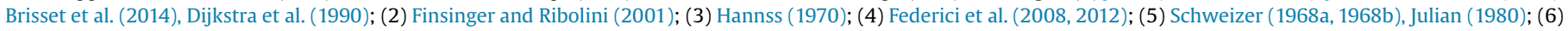

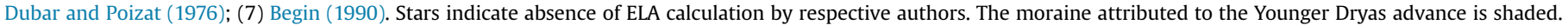
Asteriks indicates data not available in the publication of reference.

\begin{tabular}{|c|c|c|c|c|c|c|c|c|}
\hline \multirow[t]{4}{*}{ UED } & Haut-Laverq, Dormillouse, Ambouin, Allos (1) & $\delta$ ELA & 150 & 200 & $400-500$ & 600 & $600-700$ & 800 \\
\hline & & Elevation (m a.s.l.) & $2550-2600$ & $2400-2300$ & $2250-2350$ & $2050-2250$ & $1800-2000$ & $1700-2000$ \\
\hline & & ELA (m a.s.l.) & $2750-2760$ & 2750 & $2520-2600$ & $2250-2400$ & $2200-2300$ & 2100 \\
\hline & & stages & UED-VI & UED-V & UED-IV & UED-III & UED-II & UED-I \\
\hline \multirow[t]{10}{*}{ IMA } & Upper Gresso (2) & $\delta E L A$ & $50-100$ & & 200 & 300 & 500 & $>550$ \\
\hline & & Elevation (m a.s.l.) & $2500-2650$ & & $2450-2500$ & 2400 & $2054-1900$ & $1600-1700$ \\
\hline & & ELA ( $m$ a.s.l.) & $2650-2700$ & & $2600-2650$ & $2460-2570$ & $2200-2400$ & $*$ \\
\hline & & stages & rock glacier & & IMA-III & IMA-II & IMA-I & \\
\hline & Gelas Peak Northeast face (3) & $\delta E L A$ & 50 & $50-100$ & & $300-400$ & & \\
\hline & & Elevation ( $\mathrm{m}$ a.s.l.) & $2420-2620$ & $2400-2600$ & & $2050-2400$ & & \\
\hline & & ELA (m a.s.l.) & $2700-2720$ & $2700-2720$ & & 2400 & & \\
\hline & Gelas Peak Northwest face (4) & $\delta E L A$ & & & & $520-530$ & & \\
\hline & & Elevation (m a.s.l.) & & & & 1810 & & \\
\hline & & ELA (m a.s.l.) & & & & 2380 & & \\
\hline \multirow[t]{14}{*}{ FMA } & Mollières, Saint-Sauveur, Roya (5) & $\delta E L A$ & & 300 & $400-450$ & 600 & & $800-900$ \\
\hline & & Elevation (m a.s.l.) & & $2300-2700$ & $2250-2300$ & $2100-2240$ & & $1922-1650$ \\
\hline & & ELA (m a.s.l.) & & $2550-2600$ & $2500-2550$ & $2300-2400$ & & $2090-2110$ \\
\hline & & stages & & FMA-IV & FMA-III & FMA-II & & FMA-I \\
\hline & Marvels (6) & $\delta E L A$ & & 370 & 450 & 575 & 800 & \\
\hline & & Elevation (m a.s.l.) & & $2300-2450$ & $2300-2380$ & $2100-2340$ & 1760 & \\
\hline & & ELA (m a.s.l.) & & $*$ & $*$ & * & $*$ & \\
\hline & & stages & & FMA-IV & FMA-III & FMA-II & FMA-I & \\
\hline & Bégo (7) & $\delta$ ELA & & $0-325$ & $350-425$ & $450-550$ & & $550-900$ \\
\hline & & ELA (m a.s.l.) & & $2612-2892$ & $2440-2680$ & $2360-2626$ & & $1990-2450$ \\
\hline & Vens (this study) & $\delta E L A$ & & 200 & 250 & 350 & $>400$ & \\
\hline & & Elevation (m a.s.l.) & & 2700 & 2600 & 2400 & 2300 or less & \\
\hline & & ELA (m a.s.l.) & & 2800 & 2700 & 2500 & & \\
\hline & & stages & & Vens-IV & Vens-III & Vens-II & Vens-I & \\
\hline
\end{tabular}

Dryas. Stages UED-IV, V and VI, respectively at 2250-2350 m, $2500-2500 \mathrm{~m}$ and $2550-2600 \mathrm{~m}$ (ELA at 2520-2600, 2750 and 2750-2760 m, $\delta$ ELA at 500, 200 and $150 \mathrm{~m}$ ) are probably Holocene. Jorda (1975) and Jorda and Beaulieu (1977) presumed that moraine ridges of stage UED-IV, rich in fine sand, are possibly contemporary of the Preboreal Oscillation from $12,896 \pm 4$ cal. BP to $11,703 \pm 4$ cal. BP (Blockley et al., 2012). The freshest forms from UED-V and UEDVI are probably associated with the Little Ice Age (LIA; 17th-19th century).

In the IMA, glacial stages have been accurately described in the tributaries of the upper Gesso valley. The earliest observations were made by Hannss (1970) on the northeast face of Gelas Peak. This author described three stages: the lowest at $2400 \mathrm{~m}$ a.s.l. (ELA: $2050-2400 \mathrm{~m}, \delta E L A: 300-400 \mathrm{~m}$ ) is represented by blunted frontal moraine ridges attributed without dating to the Daun stadial (Maisch, 1992); the two highest stages around 2700-2720 $\mathrm{m}$ a.s.l., (ELA: $2400-2600 \mathrm{~m}, \delta E L A: 50 \mathrm{~m}$ ) are sharp ridges made of finer material, probably formed during the 17th-19th century (LIA). Later, Finsinger and Ribolini (2001) identified in the narrow valley of Vei del Bouc three stages made up of massive diamicton, and matrix-supported variably sized blocks in a sandy gravel matrix. The lower moraine ridge (IMA-I), which is locally very thick, located between 1900 and $2150 \mathrm{~m}$ a.s.l. (ELA: $2200-2400 \mathrm{~m}$, $\delta$ ELA: $500 \mathrm{~m}$ ), is situated near the mire of Vei del Bouc (2055 m) which is deglaciated since the Bölling-Alleröd pollen chronozone (GI-1e, at 14,500 cal. BP, Blockley et al., 2012). Authors have supposed that this stage could be Oldest Dryas (GS-2b, at 23,000-20,000 cal. BP, Blockley et al., 2012). Further upward, the moraine ridge IMA-II is located at $2400 \mathrm{~m}$ a.s.l., (ELA: $2500-2550 \mathrm{~m}, \delta E L A: 300 \mathrm{~m}$ ). At 2450-2500 m a.s.l. (ELA at 2600-2650 m, סELA: $200 \mathrm{~m}$ ), the IMAIII is correlated with a rock-glacier phase that developed from the apron of this moraine. At ELA of $2620 \mathrm{~m}$, which could correspond to IMA-III, Ribolini et al. (2007) dated the advance of the Schiantala

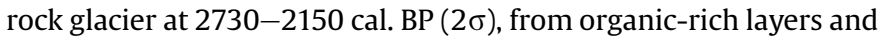
organic mats in sediment cores. The following LIA advance likely added material to the former glacial deposit and formed internal ridges of rock glaciers at $2420-2650 \mathrm{~m}$ a.s.l. [ELA: $2650-2700 \mathrm{~m}$, $\delta$ ELA: 50-100 m; Finsinger and Ribolini (2001), Hannss (1970)]. On the northwest face of Gelas Peak, Federici et al. (2008) provide a ${ }^{10} \mathrm{Be}$ date of $11,340 \pm 370 \mathrm{yr}$ constraining a frontal moraine situated at $1810 \mathrm{~m}$ a.s.l. (ELA: $2380 \mathrm{~m}$, $\delta$ ELA: $520-530 \mathrm{~m}$ ) to the Younger Dryas.

In the FMA, Schweizer (1968a, 1968b), Julian (1980) and Begin (1990) describe four stages occupying cirques. These stages, preserved in the Mollières valley, have also been found at Saint-Saveur and Roya valleys and in the valley of Marvels (Figs. 1 and 2). The oldest is the FMA-I (named Mollières stage). It is characterized by partly dismantled moraine ridges, and is located at $1650-1920 \mathrm{~m}$ a.s.l. (ELA at 2090-2110 $\mathrm{m}$ a.s.l., $\delta$ ELA: 800-900 m). Most of the moraine ridges in upper cirques in the French Maritime Alps seem to have been formed during the following FMA-II (Chastillon stage). This stage is well marked by frontal moraine ridges made of coarse material and boulders around $2100-2240 \mathrm{~m}$ a.s.l. (ELA at 2300-2400 m a.s.l., $\delta$ ELA: $600 \mathrm{~m}$ ). Locally, moraines of this stage become confused with rock glacier. Upwards, the FMA-III (Margès stage) at $2250-2300 \mathrm{~m}$ a.s.l. (ELA at $2500-2550 \mathrm{~m}$ a.s.l., $\delta$ ELA: $400-450 \mathrm{~m}$ ) is mostly made of coarse material from scree. The youngest stage is the FMA-IV (Mounier stage), commonly represented near the French/Italian boundary at 2300-2700 $\mathrm{m}$ a.s.l. (ELA at $2550-2600 \mathrm{~m}$ a.s.l., $\delta E L A: 300 \mathrm{~m}$ ). These four features are not dated. On the basis of comparisons between the glacial and pollen records in the Swiss and Austrian Alps, Schweizer (1968a) proposed that the FMA-I, II, III and IV could correspond respectively to the Schlern, the Gschnitz, the Daun and the Egesen stages which were also not absolutely dated and which were attributed at that time to the end of Lateglacial and to the Holocene period. Later, Julian (1980) suggested that FMA-I, II, III and IV could be younger, corresponding respectively to the Oldest Dryas, Younger Dryas, Preboreal and Boreal periods. In the valley of Marvels, these four stages are also well identified (Dubar and Poizat, 1976; Begin, 1990). Pollen 

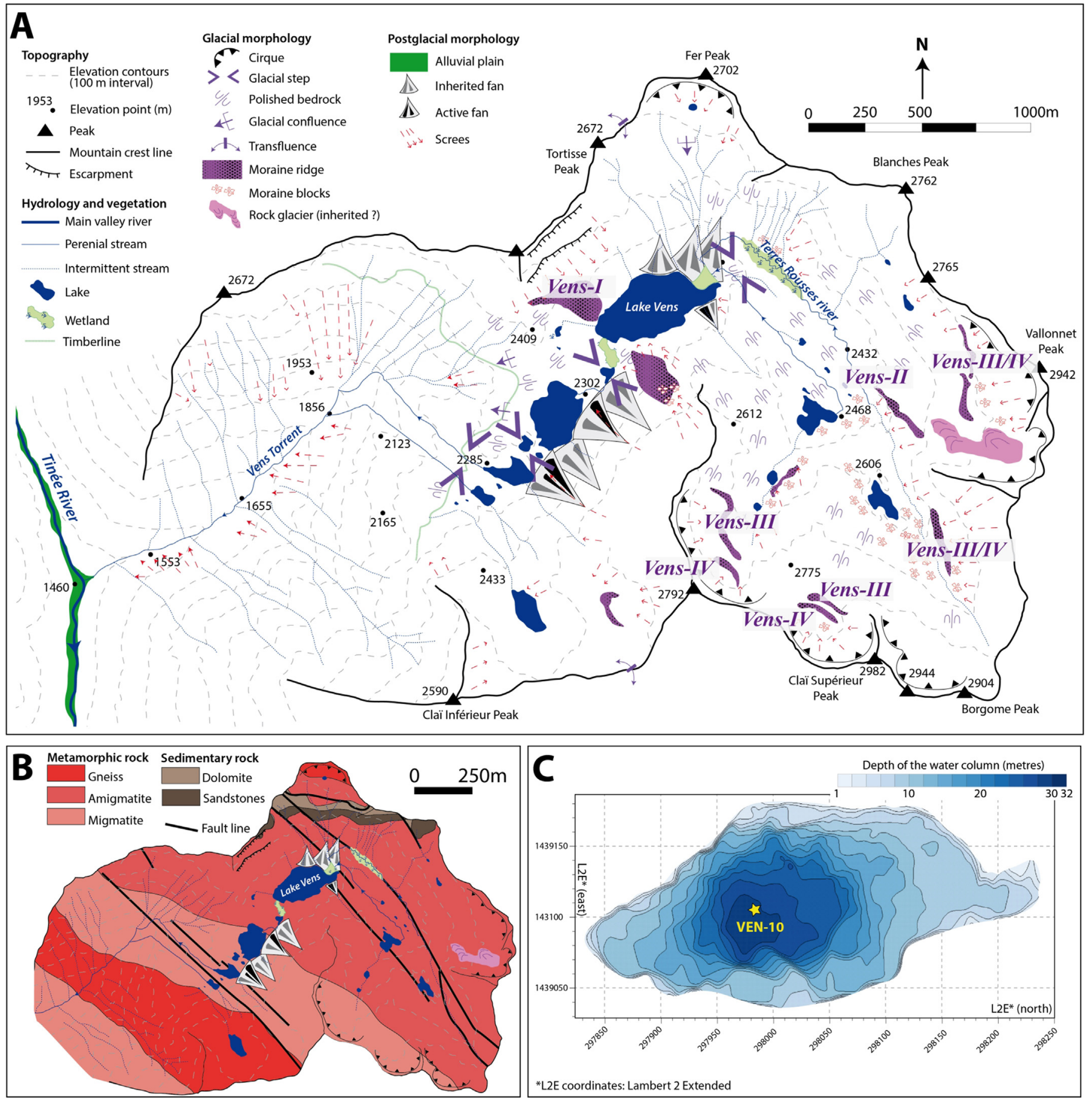

Fig. 3. (A) Geomorphological map of the Vens catchment and location of the glacial stages (stages Vens-I to Vens-IV). (B) Simplified geological map of the Vens catchment. (C) Bathymetrical map of Lake Vens.

and radiocarbon data from Lake Long Inférieur (2090 m a.s.l.; de Beaulieu, 1977) testify that the lake was already ice-free at the end of the Oldest Dryas chronozone, proving that FMA-I and FMAII, situated downstream of the lake, are older.

Finsinger and Ribolini (2001) proposed a comparison between glacial stages throughout the Mediterranean Alps and concluded that the deglaciation scheme seemed to be similar. But this comparison suffers from a lack of dating, and ELA elevations and $\delta$ ELA are noticeably different in UED, FMA and IMA (Table 1). The sediment core of Lake Vens (2330 m a.s.l.), situated between FMA-II and
III (see below), as well as a complete review of pollen and sedimentological data from all sediment cores studied in the three geographical domains, will contribute to improve and revise the time frame of the last stages of deglaciation in the Mediterranean Alps.

\section{Geomorphological setting of the Vens catchment}

The Vens catchment $\left(44.32^{\circ} \mathrm{N} ; 6.94^{\circ} \mathrm{E}\right)$ is a glacial-inherited cirque located in the northwestern part of the Maritime Alps, on 
the left bank of the Tinée valley (Fig. 3A). Catchment altitudes range from 2300 to $2980 \mathrm{~m}$ a.s.l. The main basement outcrop (Fig. 3B, $94 \%$ ) consists of Hercynian crystalline rocks (granite and gneiss). Permian-Triassic dolomite and sandstones $\left(0.24 \mathrm{~km}^{2} ; 6 \%\right.$ of the catchment) are locally preserved on northeast-facing crests. The cirque floor consists of smooth striated glacial steps and thick moraine block deposits. Several coalescent cirques gouged out on the southern slopes correspond to inherited glacier accumulation zones. Four glacial stages were recognized in the cirque (Fig. 3A). Stage Vens-I, located $2300 \mathrm{~m}$ a.s.l. at the glacial confluence of the hanging cirque of the Vens and Tinée valleys on the western flanks of Lake Vens, consists of boulders of variable size (maximum diameter of $2 \mathrm{~m}$ ) covering the polished glacial threshold (basal moraine). As this moraine is a remnant of a lateral moraine ridge, estimation of the corresponding ELA and $\delta$ ELA is hazardous. Three stages are found above Lake Vens in the Terres Rousses river valley. Stage Vens-II is a poorly preserved recessional moraine ridge positioned lengthwise relative to glacier flow at an altitude of $2400 \mathrm{~m}$ a.s.l. (ELA: $2500 \mathrm{~m}, \delta E L A: 350 \mathrm{~m}$ ). The highest ridges of stage Vens-III (2600 m a.s.l., ELA: $2700 \mathrm{~m}, \delta$ ELA: $250 \mathrm{~m}$ ) and VensIV (2700 m, ELA: 2800 m, $\delta$ ELA: 200 m) are small-amplitude endmoraines, positioned transversally to glacier flow. Vens-III and IV are well preserved below Claï Supérieur Peak while their forms are less discernible in the eastern part of the glacial cirque (undifferentiated end-moraines of Vens-III and IV). In the southeast there is evidence of a rock-glacier near to the melting point (Ribolini et al., 2007).

Lake Vens (2330 m a.s.l., $45 \mathrm{~m}$ deep, and with an area of $0.1 \mathrm{~km}^{2}$ ) is located on the longitudinal axis of the glacier tongue in a slight $\mathrm{S}-\mathrm{N}$ to $\mathrm{E}-\mathrm{W}$ bend (Fig. $3 \mathrm{~A}-\mathrm{C}$ ). The southern catchment of Lake Vens is drained by several streams flowing into the lake from block moraines. Three coalescent debris fans feed the lake intermittently.

The current timberline of Larix-Picea is located at $2200 \mathrm{~m}$. Sparse trees (Larix) are observed at $2500 \mathrm{~m}$ a.s.l. The catchment landscape is open and the vegetation characterized by a degraded alpine meadow thriving on a thin soil commonly restricted to bedrock cracks and colonising screes.

\section{Methods}

\subsection{Sedimentological analysis}

From the deepest part (45 m-deep) of Lake Vens three parallel sediment cores were retrieved in 2010 using a UWITEC piston corer in order to obtain a complete overlapping sediment sequence. Colour parameters were continuously analysed from the fresh sediment surface at $3 \mathrm{~mm}$ intervals using a Konica Minolta CM2600d spectrophotometer. The magnetic susceptibility of the sediment was measured using a Barrington MS2E surface-scanning sensor at a $1 \mathrm{~cm}$ interval. The same interval was used for the determination of water content. Wet sediment samples were weighted and dried in the oven at $105^{\circ}$ for five days and their dry weight calculated. Grain-size analysis was carried out on bulk wet sediment sampled every $2 \mathrm{~cm}$ using a Malvern Mastersizer S. The mineralogical and the micro-palaeontological composition were identified by observing sediment using a binocular and microscope.

\subsection{Pollen analysis}

Pollen analyses were carried out on 88 samples (constant volume of $4 \mathrm{~mL}$ ) that were chemically extracted following the protocol of Feagri and Iversen (1975). A minimum of 300 pollen grains were identified according to keys and pollen atlases (Moore et al., 1991; Reille, 1999). Pollen results are shown as percentages of the terrestrial pollen sum and as pollen grain concentrations (number of pollen grains per $\mathrm{mL}$ ). Subdivision into biozones of the pollen diagram (Local Pollen Assemblage Zones: LPAZ; Fig. 5) and into sedimentological units was conducted independently on the two datasets by cluster analysis using the Rioja package (Juggins, 2012). Optimal diagram partitioning has been fixed by comparison of the Bstick model (Bennett, 1996) with the Coniss model (Grimm, 1987). Significant zones/units based on the Bstick model are shown as lines, whereas exclusive Coniss significant zones are delineated by dashed lines.

\subsection{Chronology}

\subsubsection{Absolute dating and age-depth model}

Twenty-five AMS ${ }^{14} \mathrm{C}$ dates were obtained on core VEN10-II (Table 1 ). Four additional AMS ${ }^{14} \mathrm{C}$ dates and accumulation rates inferred from ${ }^{210} \mathrm{~Pb}$ obtained in a previous study of the short core VEN09P3 (Petersen et al., 2014) have been correlated to VEN10-II. Due to lack of substantial terrestrial materials, we also used bulk organic matter of the size of pollen. Centimetre-thick bulk sediment samples were chemically pre-treated to reduce initial volume and remove carbonate content (digestion in $\mathrm{HCl}$ and $\mathrm{HF}$ ) and sieved to concentrate the fraction size between 10 and $160 \mu \mathrm{m}$. Conventional ${ }^{14} \mathrm{C}$ ages are were calibrated (cal. BP) using the IntCal13 curve (Reimer et al., 2013) based on the 2 sigma interval. The age-depth model has been computed for the corrected depth taking into account continuous sedimentation processes using the module Clam of Blaauw (2010) based on a cubic spline (type $=4$, smooth $=0.65$, $95 \%$ probability). The Age-Depth Model (ADModel) derived age is reported using the 2 sigma interval cal. BP.

\subsubsection{Relative pollen biostratigraphy}

A large number of pollen studies over the last decades have provided a detailed overview of local to regional-scale vegetation changes. As proposed by Van der Knaap et al. (2005), pollen trends that depend with reasonable certainty directly on dated climate forcing are used to correlate pollen diagrams of nearby sites, including the transitions Alleröd to YD and YD to Preboreal (Holocene). Hence, by comparing Local Pollen Assemblage Zones (LPAZ) of individual sites with the large-scale biostratigraphical framework, chronologies of records lacking relevant ${ }^{14} \mathrm{C}$ ages can be significantly improved. Inter-sites palynological comparisons must be conducted taking into account the altitudes of sites and their biogeographical domains. Therefore, lowland sites only record discrete pollen changes during major climatic events, Lotter et al. (1992) pointing out that cool events (such as the Younger Dryas) could only be recorded at higher altitude sites, which are more sensitive. In addition, colonisation by meso-thermophilous trees during the Holocene might not be strictly contemporaneous between two sites because of possible migration lag depending on distance from glacial refuges (Birks and Line, 1992).

Comparison between the VEN10-II LPAZs and local biostratigraphy is therefore based on independent dated sites on which: (1) pollen sampling resolution is accurate for a specific discussed period, and (2) palynostratigraphical assignment is well constrained for the stated period.

\section{Results}

\subsection{Lithostratigraphy and sedimentology}

The composite core of VEN10-II shows five distinct lithotypes (Fig. 4A) characteristic of lacustrine background sedimentation (from LT-A to LT-C) and of instantaneous events (from LT-D to LT-E). The significant stratigraphical units (Fig. 4) have been defined using cluster analysis on the background lacustrine sedimentation 
exclusively. The lowermost unit $1(\mathbf{9 0 9}-\mathbf{6 2 0} \mathbf{~ c m})$ is dominated by laminated, light-blue to beige ( $\mathrm{L}^{*}>45$ ), clay silt alternations (LTC2). Water content is minimum (mean of $30 \%$ ). Values of magnetic susceptibility are high (between 120 and $60 \times 10^{-5} \mathrm{SI}$ ). Microscopic observations reveal the presence of alumino-silicate minerals (quartz, feldspar) and detrital carbonate. Particle size distributions of blue layers are normally distributed around a mode at $4-15 \mu \mathrm{m}$. In beige layers, particle size distributions are unimodal and less well sorted (mode at 15-25 $\mu \mathrm{m}$ ). At the bottom of the core, sediment is composed of matrix-supported coarse magnetic gneissic material reworked from moraine deposits (LT-E2; $S M=120 \times 10^{-5}$ SI). Several peaks of coarser grain size are indicated by the lithotype LT-D3 (grain size mode at $100-500 \mu \mathrm{m}$ ). From 720 to $620 \mathrm{~cm}$, the water content increases to $40 \%$ together with the appearance of darker laminations (alternation of clay silt LT-C2 and LT-C1). Unit 2 $(620-490 \mathrm{~cm})$ is characterized by light blue to brown laminations (LT-C1). Values of magnetic susceptibility drop to $12 \times 10^{-5} \mathrm{SI}$. Between 530 and $556 \mathrm{~cm}$, clayey sedimentation is interrupted by one $28 \mathrm{~cm}$ thick layer of very coarse gravels (LT-E1), and by thin sandy layers (LT-D3). In unit $3 \mathbf{( 4 9 0 - 3 9 5} \mathbf{~ c m})$, laminations become progressively finer and darker (LT-B). Water content increases to $60 \%$. In unit $4(395-245 \mathrm{~cm})$, lamination disappear and the sediment becomes a homogeneous dark brown gyttja (wavelength ratio $680 / 510 \mathrm{~nm}$ of the colorimetric analysis of 1.5 ). In this unit, light grey sand-graded layers (LT-D2) are interbedded in the predominant lithotype LT-A2. Water content reaches about $75 \%$ in the whole of unit 4. Grain size is coarser in this unit (around 50\% of the sample volume comprises sizes $>63 \mu \mathrm{m}$ ). Binocular observations indicate that these samples are mainly composed of diatom valves and colonies with sizes ranging from 100 to $1000 \mu \mathrm{m}$, and to a lesser extent of amorphous red organic matter. The sediment is rich in plant and algal microfossils and in wood macrofossils. Unit $\mathbf{5}$ $(\mathbf{2 4 5}-\mathbf{0} \mathbf{~ c m})$ is characterized by alternating LT-A2 and LT-A1. In LT$\mathrm{A} 2$, the diatom gyttja is homogeneous whereas in LT-A1 diatom gyttja is episodically intercalated with layers of beige detrital carbonates. This sequence comprises variably thick $(10-22 \mathrm{~cm})$ interbeds of instantaneous sediments (LT-D1 and LT-D2). Mean water content is about 75\% in LT-A1 and drops to lower values (45\%) in the instantaneous sedimentation (LT-D1 and LT-D2).

\subsection{Pollen zones}

Six Local Pollen Assemblage Zones (LPAZ 1 to LPAZ 6) were defined according to cluster zoning (Fig. 5), such that the pollen diagram is described in terms of major changes in vegetation assemblages. Pollen spectra from 909 to $793 \mathrm{~cm}$ are characterized by low pollen concentration (Fig. 5) and were sampled in blue sandy clay deposits. Hence, rare pollen grains observed in this sub-sterile section might be considered as pollution or reworked material.

LPAZ 1 (from 792 to $710 \mathrm{~cm}$ ) is dominated by arboreal pollen (82\%), mostly bounded by Pinus sylvestris. Non-arboreal pollen assemblages are characterized by alpine plants (Chenopodiaceae, Artemisia, Poaceae and Thalictrum). Sporadic grains of Quercus deciduous, Corylus and Abies suggest long-distance pollen transport from lower altitudes. The curve of Juniperus, a low pollen disperser $(0.5 \%)$, is continuous.

LPAZ 2 (from 710 to $620 \mathrm{~cm}$ ): Arboreal pollen and Pinus percentages decrease abruptly to $45 \%$ and tree pollen concentrations decrease. High values of Poaceae, Chenopodiaceae and maximum values of Artemisia (25\%) and Ephedra distachya suggest a cold steppe of herbs/shrubs.

In LPAZ 3 (from 620 to $460 \mathrm{~cm}$ ) herbaceous steppe taxa (Thalictrum, Artemisia, Poaceae) decrease concomitant with a reexpansion of Pinus and a general diversification of tree taxa (presence of Tilia and continuous curve of deciduous Quercus). In
LPAZ 3b, steppe taxa of Artemisia and Poaceae decline. The Abies curve starts at values of $7 \%$.

LPAZ 4 (from 460 to $370 \mathrm{~cm}$ ) Abies decreases to 1\% while leaftrees reached their maximum values (Betula, Tilia, and Corylus). The first occurrences of deciduous tree macrofossils (Alnus, Betula and Salix) are observed, indicating expansion of leaf-trees.

LPAZ 5 (from 370 to $300 \mathbf{~ c m}$ ) is marked by the Abies optimum (30\%) and the first significant decline of Pinus. The abundance of conifer macrofossils indicates the local expansion of mixed conifer forests. The first occurrences of Larix and Picea are signs of more open woodland.

LPAZ 6 (from 300 to $\mathbf{0 ~ c m}$ ) is characterized by low occurrences of terrestrial macrofossils and a decline of tree taxa (30\%), suggesting a sparse distribution of trees in the catchment. High concentrations of herb taxa indicate a local development of diversified alpine steppe (Poaceae, Artemisia, Chenopodiaceae, Asteroideae and other herbs) associated with ruderal-anthropogenic herbs (Rumex and Urtica). The first pollen occurrence of cultivated trees Castanea and Juglans is observed at $244 \mathrm{~cm}$.

\subsection{Combination of radiocarbon age and ${ }^{210} \mathrm{~Pb}$ accumulation rate}

Table 1 shows results of the twenty-nine AMS radiocarbon ages of core VEN10-II. Fifteen radiocarbon dates on terrestrial plant macroremains (exclusively from 430 to $270 \mathrm{~cm}$ and from 47 to $37 \mathrm{~cm}$ ) and ten on bulk organic matter of the size of pollen (pollenconcentrated organic matter) have been retrieved from the continuous sediment accumulation. All macroremain samples contained more than $1 \mathrm{mg}$ of carbon and are therefore probably not contaminated by younger carbon (Wohlfarth et al., 1998). In addition we report from Petersen et al. (2014) (1) four ${ }^{14} \mathrm{C}$ dates of unknown organic debris sampled from reworked deposits (homogenite-type) giving a maximal age for the deposit and (2) a ${ }^{210} \mathrm{~Pb}$-derived accumulation rate of $0.7 \mathrm{~mm}^{\circ} \mathrm{a}^{-1}$ covering the interval from 9 to $0 \mathrm{~cm}$. The age results (Fig. 6) suggest various hypotheses for the age-depth model. To better constrain the chronology, we propose using biostratigraphical markers, in particular for the early lake formation and for the last 2000 years.

\section{Interpretations}

\subsection{Main vegetation changes at Vens and inter-site comparisons}

In this paragraph, the simplified Vens pollen record is interpreted both in terms of major landscape changes and palynostratigraphical correlations with other regional pollen records (Fig. 7).

\subsubsection{LPAZ 1: predominance of Pinus (correlated to the Alleröd)}

This pollen zone is dominated by Pinus whereas Betula is poorly represented. The scarcity of Betula confirms that the base of the pollen record cannot be contemporaneous with the Bölling, marked by an optimum of birch woodlands in the Alps. This zone is characterized by relatively low herb pollen diversity but is dominated by Poaceae and Artemisia. Such pollen assemblages are comparable with those recorded in the Italian piedmont (Vescovi et al., 2007), the Southern Alps (Ponel et al., 2011), the Inner Alps (David et al., 2001; Ammann et al., 2007) and the Jura Mountains during the second part of the Alleröd (Magny et al., 2006). At Long Inférieur (De Beaulieu, 1977), the predominance of Pinus is also recorded during this period, characterized at a global scale by climatic warming initiated during the Bölling (Larocque and Finsinger, 2008; Lischke et al., 2013). This climatic improvement allowed rapid forest recolonisation, characterized in particular by a general development of pine forests in all European mountain areas 
the alpine range. The pollen records of Vens and Long Inférieur support this hypothesis; at Vens, this is particularly well illustrated by a transitional curve prior to the maximal expansion of Abies recorded typically during the Atlantic synchronously with Larix (event e in Fig. 7). It can be assumed therefore that the onset of regular occurrences of fir might be contemporaneous with the first occurrences observed at the Lateglacial/Holocene boundary at Long Inférieur and at Sabion (de Beaulieu, 1977).

\subsubsection{LPAZ 5 (correlated to the Boreal $-d$ )}

This zone is marked by a declining curve of Abies, a synchronous optimum of Corylus, Tilia, and secondary deciduous Quercus classically recorded during the Boreal in the Alps around 10,000 cal. BP. This event is dated in the Southern Alps at 11,100-9780 cal. BP at Forest en Devoluy (de Beaulieu, 1977), between 9500 and 10,300 cal. BP at Mouton (de Beaulieu, 1977), and between 10,390 and 10,010 cal. BP at Lauzons (Ponel et al., 2011).

\subsubsection{LPAZ 5 (correlated to the Atlantic - e)}

The maximal expansion of Abies and the development of Larix are the major characteristics which allow assigning the pollen zone to the Atlantic period: as evidenced by Muller et al. (2007) and Van der Knaap et al. (2005), the optimum of fir in the Alps occurred within the period between 8500 and $6000 \mathrm{cal}$. BP. This event is dated in the Southern Alps at 8310-7880 cal. BP at Plan du Laus (De Beaulieu, 1977), between 8090 and 7400 cal. BP at Mouton (ADModel, De Beaulieu, 1977), at 8310-7880 cal. BP at Saint Léger (Digerfeldt et al., 1997) and between 8460 and 6730 cal. BP at Lauzons (ADModel, Ponel et al., 2011).

\subsubsection{LPAZ 6 (correlated to Subboreal/Subatlantic - $f, g, h$ )}

This pollen zone is marked by a general decline of tree pollen while ruderal-anthropogenic herb frequencies reach their highest values. This period (corresponding to the onset of event "f") corresponds to a regression of fir forests and consecutive expansion of Fagus, a competitive tree, together with Picea. The expansion of beech characterizes the onset of the Subboreal in the Alps (dated between 6800 and 5700 cal. BP, Magri, 2008). In the Southern Alps, continuous low values of Fagus are dated at 6630-6310 cal. BP at Long Inférieur (De Beaulieu, 1977), at 6980-6300 cal. BP at Plan du Laus (De Beaulieu, 1977), at 6270-5750 cal. BP at Saint Léger (Digerfeldt et al., 1997), and at 6470-6210 cal. BP at Lauzons (Ponel et al., 2011).

The transition between the Subboreal and the Subatlantic is classically based on the Juglans line, i.e., the first regular occurrences of Juglans in the Southern Alps (De Beaulieu, 1977). Juglans disappeared from Europe during or before the last glaciation, and spread from Middle East refuges (Zohary and Hopf, 2000; Conedera et al., 2004) and into Southern Europe (Carrion and SanchezGomez, 1992) during the Holocene. According to Beug (1975), Juglans is considered in the Mediterranean area as a domesticated tree, cultivated during the Gallo-Roman period in Southern Europe. As suggested by Bottema (1980), the appearance of Juglans might have been asynchronous in Europe, partly determined by distance from refuges. Therefore, several authors have proposed that walnut might have been present earlier than assumed in Spain (LopezGarcia and Lopez-Saez, 2000) and in the Italian peninsula before Roman times (Mercuri et al., 2013). However, again according to Mercuri et al. (2013), the concomitant increase in Olea, Juglans and Castanea frequencies (named the OJC group) has been favoured by intensification of cultivation during Hellenistic and Roman times. Following this, the OJC Group expansion occurred during the middle Ages in the course of event "h" in Fig. 7 (Mercuri et al., 2013). Lastly, in the Alps, most ages obtained for the "Juglans line" confirm that walnut is a relevant indicator of the Roman period at about 2000 cal. BP (De Beaulieu, 1977; Clerc, 1988; David, 1993; Brugiapaglia, 1996; Ortu, 2002; Court-Picon, 2007). Two very recent studies of Lake Petit ( $2200 \mathrm{~m}$ a.s.l., $30 \mathrm{~km}$ distant from Vens) in the Southern Alps have allowed dating the Juglans line (event "g") at 2360-1980 cal. BP and the OJC group expansion in event $h$ at between 1580 and 1350 cal. BP (ADModel, Brisset et al., 2012, 2013).

\subsection{Establishing the Lake Vens multiproxy age-depth model}

The palynostratigraphical markers defined above provide a constrained chronological framework to compare the ${ }^{14} \mathrm{C}$ ages of core VEN10-II (Figs. 5-7):

- From 909 to $440 \mathrm{~cm}$ : sediment is organic-poor and the ${ }^{14} \mathrm{C}$ samples at 569 and $705 \mathrm{~cm}$ are respectively dated to $16,710-16,190 \mathrm{cal}$. BP and 17,100-16,550 cal. BP from pollenconcentrated organic matter. These ages are at least 3000 years older than expected from the regional palynostratigraphy, thus indicating that the Lake Vens infilling started during the Alleröd chronozone. Moreover, the pollen stratigraphy (Fig. 7) indicates that the ${ }^{14} \mathrm{C}$ age at $450 \mathrm{~cm}$ dated at $12,430-12,720 \mathrm{cal}$. $\mathrm{BP}$ is inconsistent with the beginning of the Holocene period at $570 \mathrm{~cm}$. These three ${ }^{14} \mathrm{C}$ ages are, thus, incompatible with the palaeoclimatic event stratigraphy of the INTIMATE group that dated the GI-1c at 13,954 (+30/-10) cal. BP and the GS- 1 from $12,896 \pm 4$ cal. BP to $11,703 \pm 4$ cal. BP (Blockley et al., 2012). Consequently, the ${ }^{14} \mathrm{C}$ ages of pollen-concentrated organic matter have been rejected in this depth interval;

- From 500 to $280 \mathrm{~cm}$ : most of the ${ }^{14} \mathrm{C}$ ages are in conformity with the regional palynostratigraphy (10 ages). Wood macrofossils are abundant at these depths and except for three of these samples obviously older and probably reworked from the lake catchment (at depth of 278,364 and $412 \mathrm{~cm}$ ), all the ${ }^{14} \mathrm{C}$ age have been used to construct the age-depth model.

- From 280 to $0 \mathrm{~cm}$ : The comparison of the $6{ }^{14} \mathrm{C}$ ages from bulk organic matter of pollen size and the palynostratigraphy indicates an offset of 2000 years. Two ${ }^{14} \mathrm{C}$ ages of undifferentiated plant debris retrieved from reworked deposits are in agreement with the pollen stratigraphy while one might be rejuvenated and the second one might be older. A younger ${ }^{14} \mathrm{C}$ age might be due to sample contamination as a result of a low carbon concentration in the sample. This plant debris probably originated from older sediments reworked during an erosional phase in the course of these events. The two upper ${ }^{14} \mathrm{C}$ ages (terrestrial macrofossils from continuous accumulation) are in agreement with the ${ }^{210} \mathrm{~Pb}$ accumulation rate (Petersen et al., 2014) and the regional palynostratigraphy.

The age-depth model is built from 12 accepted ${ }^{14} \mathrm{C}$ AMS ages and 8 palynostratigraphical markers (Fig. 8). The 2 sigma envelop of the age-depth model encompasses three rejected ${ }^{14} \mathrm{C}$ ages (two from reworked deposits and one from pollen-concentrated organic matter) which have not been included for model calculation and might consequently be accepted. On the whole, core VEN10-II covers at least the last 13,000 years, with a maximal age at 14,000 cal. BP.

Comparison between the palynostratigraphical results and ${ }^{14} \mathrm{C}$ ages at Vens has demonstrated a distinct offset. ${ }^{14} \mathrm{C}$ dating of pollenconcentrated organic matter was conducted in order to compensate for the absence of terrestrial macrofossils. This study shows that these ${ }^{14} \mathrm{C}$ ages are systematically older than expected.

- In the early stages of lake infilling from $13,000-14,000$ cal. BP to 10,000 cal. BP, contamination by old carbon could be due to reworking of (1) old pollen, (2) old soil organic matter, (3) dead 


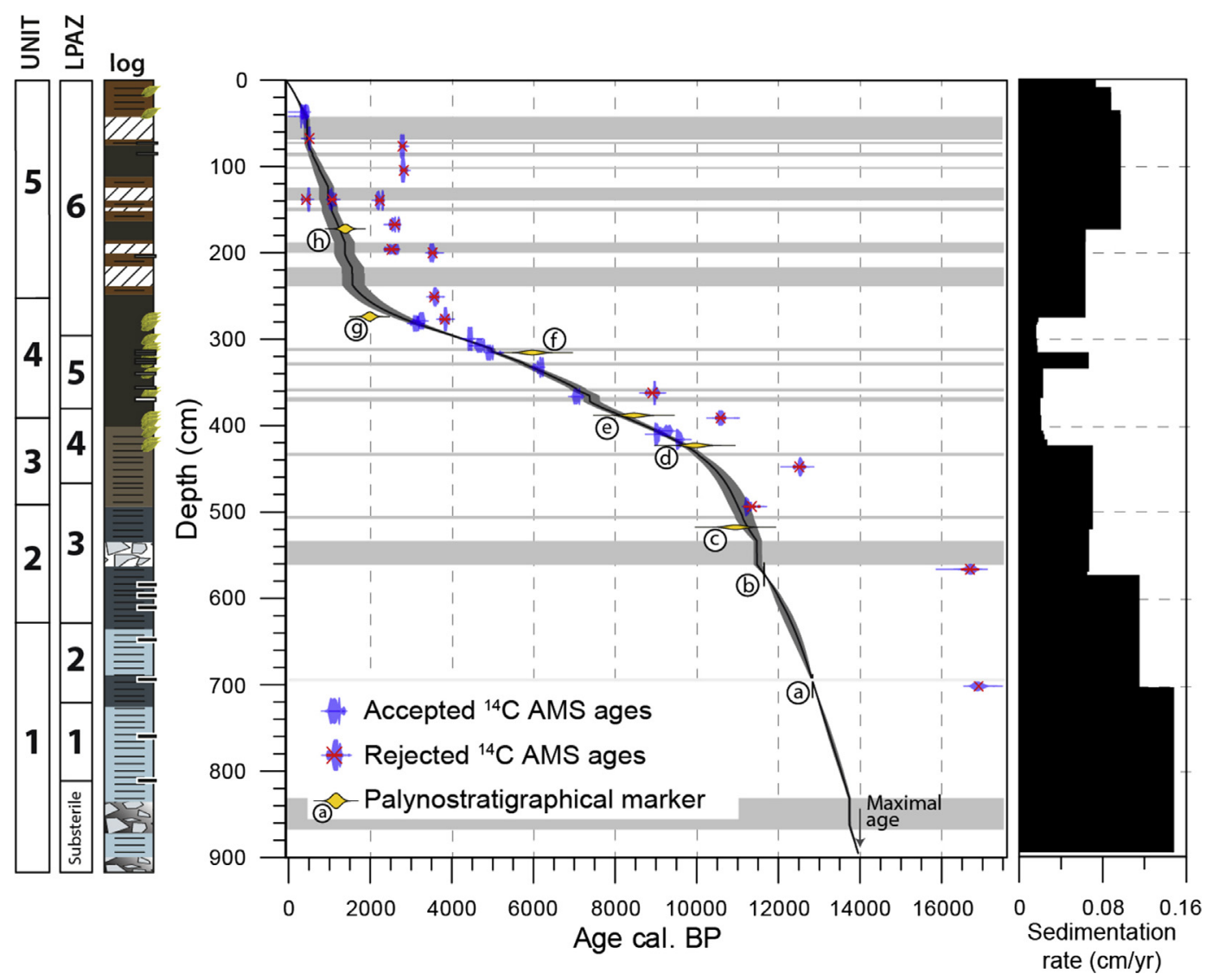

Fig. 8. Multi-proxy age-depth model of core VEN10-II computed on the basis of ${ }^{14} \mathrm{C}$ AMS ages of terrestrial material sampled from the continuous lacustrine sedimentation. These ages are supported by palynostratigraphical interpretations (markers "a"-“h"). Instantaneous deposits (shaded bands) larger than $1 \mathrm{~cm}$ were removed before modelling. Three ages rejected a priori are accepted a posteriori (see text for explanations).

carbon from dolomite bedrock and (4) coal particles (Björck and Wohlfarth, 2001). As shown by inter-site comparison of the pollen stratigraphy, the sediment sequence of Vens records the succession of expected biostratigraphical events and thus we suggest that pollen grains are not reworked. The first sign of local steppe vegetation is recorded since the formation of the lake and even if landscapes were probably sparsely vegetated, it can be assumed that soil development (source of old carbon) might have accompanied pine and juniper shrublands. Early development of Podzols in Alpine granitic environments has been dated at $14,900 \pm 1800-14,300 \pm 2300$ years (Lateglacial Interstadial) and at the end of the YD at ca 10,700 \pm 900 and $8600 \pm 600$ years (Favilli et al., 2009; Egli et al., 2010; Böhlert et al., 2011). The two deepest samples at 705 and $604 \mathrm{~cm}$ suffer from residual, black and vitrified, undeterminable particles $(5-20 \mu \mathrm{m})$ which could be associated with wind-dispersed coal particles (Björck and Wohlfarth, 2001) or dead carbon from dolomite bedrock.

- In the third tier of the Holocene from 3000 to $500 \mathrm{cal}$. BP, the six ${ }^{14} \mathrm{C}$ ages on pollen-concentrated organic matter samples have an almost unchanging offset of $\sim 2000$ years ( $1820 \pm 215$ years, $2 \sigma$ ) relative to the age-depth model. Before $3000 \mathrm{cal}$. BP, the lake catchment was densely forested (optimum values of Abies and high pollen concentration), which probably promoted soil development and lower detrital inputs (Mourier et al., 2010; Böhlert et al., 2011). At 3000 cal. BP, a more open landscape characterized by the development of ruderal-anthropogenic meadows (optimum of Rumex and Urtica) is accompanied of an increase in detrital inputs. Vegetation reversal in response to increasing anthropogenic pressure in the catchment might have led to soil dismantling providing old refractory organic matter for sedimentation in the lake. Considering that the ${ }^{14} \mathrm{C}$ result interval of $3800-2100$ cal. BP $(2 \sigma)$ is relatively narrow and coincides with a period of intense anthropogenic pressure, we suggest these ages as illustrating the last stages of soil development in the lake catchment before their dismantling.

\subsection{The palaeoenvironmental history recorded at Vens}

\subsubsection{The Lateglacial}

Between $\sim 14,000$ and $\sim 13,100$ cal. BP: the lithotype consisting of light blue fine silts to beige medium silts is characteristic of a depositional environment in the distal position of a proglacial lake ("glacial milk"). Sedimentation rates are maximal $\left(0.14 \mathrm{~cm}^{\circ} \mathrm{a}^{-1}\right)$. The sediment is rich in magnetic minerals from the gneissic bedrock. This is the sedimentological expression of erosion and removal of a glacier tongue located upvalley that steadily fed the lake. Non-graded sandy layers occurred repeatedly and could indicate debris flows occurring during high-discharge events. The development of steppe vegetation is not documented in the sediment record which is free of organic matter. Clastic particles were hence deposited under the strong influence of proglacial processes. Our results allow dating the lake formation from the Alleröd. Therefore, the moraine Vens-I was deposited before $14,000 \mathrm{cal}$. BP, and disconnection of the cirque glacier of Vens from the main tongue of the Tinée valley occurred prior to this date. 
Between $\sim 13,100$ and $\sim 12,700$ cal. BP: thick laminations of clay and silt are associated with high values of magnetic susceptibility. Darker laminations indicate a reduction of glacier release during the Alleröd. The presence of an open forest colonising slopes around the lake may have promoted organic matter release. The local glacier probably receded upstream in the cirque, favoured by the warmer conditions of the end of the Alleröd. This phase of glacier retreat and open forest development is interrupted at $\sim 12,700$ cal. BP by the re-appearance of light blue laminations interpreted as a lacustrine facies in a proglacial distal position.

Between $\sim 12,700$ and $\sim 12,300$ cal. BP, the vegetation records a strong reversal towards a steppe environment in response to probably colder conditions during the YD event. Rapid vegetation changes together with a higher influence of glaciolacustrine processes might be a signature of glacier tongue advance in the cirque floor probably resulting in the formation of moraine ridges. This phase may be related to the lowermost Vens-II moraine. This could easily explain the reoccurrence of highly minerogenic facies. Alternatively, the two upper moraines, Vens-III and Vens-IV moraines, were also built by short cirque glacier fluctuations during the same cold YD event. Alternatively, and taking into account (1) the relative fresh morphology of the ridges of Vens-III and IV, (2) the foothill position and (3) northerly exposure of the cirque, they may have been constructed later during the Holocene.

\subsubsection{The Holocene}

Between 12,300 and 11,000 cal. BP: sediment is composed of light blue to brown clay silt laminations. The sharp lowering of magnetic susceptibility values suggests weakening of erosion of the gneissic bedrock, and the increasing water content suggests less massive mud deposition. The sedimentation rate drops from 0.11 to $0.07 \mathrm{~cm}^{\circ} \mathrm{a}^{-1}$, indicating a lowering of terrigenous inputs. The decrease in glacial erosion probably reflects significant melting and retreat of the glacier or even its demise. Even if the catchment was no longer under glacier influence, the steppe cover and the lack of organic material indicate deposition during the cold conditions of the end of the YD. Such conditions are compatible with the presence of residual ice pack shaping the small-amplitude moraine ridges Vens-III and Vens-IV. The occurrence of an isolated "scree" layer of gneissic material in the lake sediment at $\sim 11,500$ cal. BP can be explained by mass wasting of the scree/moraine deposits Vens-I which covered the flanks of Lake Vens.

Between $\sim 11,000$ and 8500 cal. BP: the sediment is characterized by a progressive increase in water content and organic matter accompanied by darker silty laminations. Leaf tree expansion around the lake, together with the first occurrences of wood macrofossils, attest to the establishment of a riparian forest. A reduction of terrigenous inputs reflects the stabilisation of the catchment slopes.

Between 8500 and 1700 cal. BP: a homogeneous to laminated dark brown diatomite gyttja is deposited. These sediments document an increase in algal organic productivity probably reflecting warmer conditions. This unit is marked by the optimum in abundance of plant remains. The sedimentation rate reaches its lowest values, reflecting the reduction of terrigenous inputs and catchment stabilisation.

From 1700 cal. BP to Present: the recurrence of a laminated facies is marked by an alternation of dark brown gyttja and light beige detrital layers. The sedimentation rate increased to values close to the ante-Holocene period. The plant cover is dominated by ruderal-anthropogenic herbs attesting to the primacy of anthropogenic activities in generating an open landscape. A reduction in the extension of forest might have led to increased soil vulnerability and consequently promoted terrigenous inputs. The occurrence of homogeneous matrix-supported deposits also reflects this destabilisation (Petersen et al., 2014). Increasing sediment loads on lake slopes probably triggered mass-wasting events.

Since lake formation at ca 14,000 cal. BP, the catchment experienced the last cirque glacier pulsations followed by a general reduction in erosion processes during catchment reforestation. Lastly, an increase in erosion processes consequent to this preceding quiescent phase occurred due to anthropogenic influences. Since the end of the Younger Dryas, the catchment has not experienced cirque glacier tongue advance. Even though residual glaciers/ice-packs might have persisted during the Holocene in restricted foothill areas (Vens-III and IV), they did not influence catchment dynamics.

\subsection{Time frame and geographical characteristics of the cirque- glacier deglaciation of the Mediterranean Alps}

We have built up our analysis on the basis of a corpus of 15 highelevation lake and mires sediment core studies of the Mediterranean Alps enhanced by the Lake Vens record (Fig. 1B and Supplementary Material). On each site, we examine three independent observations: (1) lithology documenting environmental changes; (2) radiocarbon ages and type of sample material (Table 2); and (3) local pollen assemblage zones (LPAZ) as they were defined by authors. Radiocarbon ages inconsistent with palynostratigraphy were rejected. The synthesis of these data are represented schematically in Fig. 9A and yields new insight into the chronology of deglaciated environments by providing information on: (1) the early stage of lake formation (bottom core dating), (2) phases of the deglaciation of the cirque glacier upvalley, and (3) geographical settings (altitude and ice-free catchment exposure).

\subsubsection{An updated chronology of the cirque-glacier deglaciation in} the southern Mediterranean Alps

7.4.1.1. Ice-free high altitude cirques since the onset of the Bölling-Alleröd (GI-1e). The pollen diagram of Lake Vens attests that at an elevation of $2300 \mathrm{~m}$ a.s.l., the lake was ice-free before the onset of the Alleröd, i.e. 14,500 cal. BP (GI-1e, Blockley et al., 2012). Eight additional lakes and mires (Long Inférieur $(2090 \mathrm{~m})$ and Orgials $(2240 \mathrm{~m})$ in the FMA, Vei del Bouc (2055 m) in the IMA, in Allos $(2225 \mathrm{~m})$, Vallon de Provence $(2075 \mathrm{~m})$, Terres Plaines $(2100 \mathrm{~m})$, Restefond $(2400 \mathrm{~m})$ and Vallon du Loup $(2010 \mathrm{~m})$ in the UED) provide the same scheme showing that cirques above $2000 \mathrm{~m}$ a.s.l. are deglaciated since the Bölling-Alleröd or even since the end of the Oldest Dryas. Lake Long Inférieur provides the oldest relevant ${ }^{14} \mathrm{C}$ age supporting the chronology of an ice-free lake bottom at $13,740-13,410$ cal. $\mathrm{BP}(2 \sigma)$. Glacial retreat in uplands is also attested by the ${ }^{10} \mathrm{Be}$ ages obtained on polished surface samples in the French Maritime Alps (Fer/Rabuons catchments; Darnault et al., 2012), which indicate that cirques were deglaciated at $14,914 \pm 809$ years (2700-2800 $\mathrm{m}$ a.s.l.). Consequently, the moraine ridges situated downstream of the mires and lakes mentioned above must belong to the first part of the Lateglacial period; glacial deposits situated upstream must be related to cooling during the Younger Dryas and the Holocene.

7.4.1.2. Oldest Dryas glacial remains. At Vens, the oldest glacial deposits are situated near the lake at $2300 \mathrm{~m}$ a.s.l. (Vens-I); downvalley no stage has been found probably because of the steepness of the slopes. These glacial remains could correspond to FMA-I and to one of the two Oldest Dryas stages identified in the UED (UED-I or II). There are no arguments in favour of which one is related to the FMA-I. In the IMA, stage IMA-I identified in Gesso valley could also correspond to the oldest stages of UED (UED-I or II) and FMA-I (Finsinger and Ribolini, 2001). These authors also map moraine at $1700 \mathrm{~m}$ a.s.l. (Fig. 2); considering the elevation of these 


\section{Table 2}

Compilation of sediment core studies in the Mediterranean Alps from a) Brisset et al. (2014); b) Ortu et al. (2005); c) Ortu (2002); d) Kharbouch (2000); e) Richer (2009); f) De Beaulieu (1977); g) Ponel et al. (2001); h) Gandouin and Franquet (2002); i) Brisset et al. (2012); j) Brisset et al. (2013); k) Dijkstra et al. (1990); l) Jorda and de Beaulieu (1977); m) Finsinger and Ribolini (2001); n) Finsinger (2001). Site selection is based on a minimal dataset of lithological descriptions and palynological diagrams. A numerical code reference is attributed to each lake refers in Fig. 1 (localisation map). Asterisks indicate unavailable data (material dated and/or $\delta^{13} \mathrm{C}$ ). Imprecise core correlation of ${ }^{14} \mathrm{C}$ age is coded "IC". Column remarks are an interpretation on the validity of the ${ }^{14} \mathrm{C}$ ages: "suspect" means that age is inconsistent with palynostratigraphy of the respective core, "rejected" means that age is discarded. Italics indicate the rejected ${ }^{14} \mathrm{C}$ ages.

\begin{tabular}{|c|c|c|c|c|c|c|c|c|c|c|c|c|c|c|}
\hline Code & $\begin{array}{l}\text { Name and } \\
\text { reference }\end{array}$ & $\begin{array}{l}\text { Lat } \\
(\mathrm{N})\end{array}$ & $\begin{array}{l}\text { Long } \\
\text { (E) }\end{array}$ & $\begin{array}{l}\text { Altitude } \\
\text { (m asl) }\end{array}$ & Aspect & $\begin{array}{l}\text { Sample } \\
\text { code }\end{array}$ & $\begin{array}{l}{ }^{14} \mathrm{C} \text { age } \\
\text { uncal. BP }\end{array}$ & $\begin{array}{l}\text { Error } \\
(2 \sigma)\end{array}$ & $\begin{array}{l}\text { Min cal. } \\
\operatorname{BP}(2 \sigma)\end{array}$ & $\begin{array}{l}\text { Max cal. } \\
\text { BP }(2 \sigma)\end{array}$ & $\begin{array}{l}\text { Core } \\
\text { depth } \\
(\mathrm{cm})\end{array}$ & Material & $\delta^{13} \mathrm{C}$ & Remark \\
\hline \multirow[t]{19}{*}{1} & Allos & 44.13 & 6.42 & 2225 & $\mathrm{~N}$ & Poz-50232 & 615 & 35 & 546 & 658 & 181 & Wood and needles & * & \\
\hline & $-a$ & & & & & Poz-49766 & 1275 & 30 & 1098 & 1289 & 250 & Needles & $*$ & \\
\hline & & & & & & Poz-49767 & 1645 & 30 & 1417 & 1617 & 300 & Conifer bark & $*$ & \\
\hline & & & & & & Poz-49768 & 1795 & 30 & 1622 & 1818 & 390 & Herbaceous fragments & $*$ & \\
\hline & & & & & & Poz-46760 & 2880 & 35 & 2885 & 3142 & 498.5 & Twig - Salix sp. & $*$ & \\
\hline & & & & & & Poz-46759 & 3060 & 35 & 3177 & 3360 & 525 & Twig - conifer (Larix/Picea) & $*$ & \\
\hline & & & & & & Poz-50223 & 2900 & 40 & 2898 & 3164 & 556 & Twig deciduous tree & $*$ & \\
\hline & & & & & & Poz-46758 & 3895 & 35 & 4184 & 4422 & 589 & Twig of deciduous tree & $*$ & \\
\hline & & & & & & Poz-50227 & 4090 & 35 & 4444 & 4812 & 605 & Charcoal (Gymnosperme) & $*$ & \\
\hline & & & & & & Poz-50231 & 8840 & 50 & 9705 & 10,158 & 660 & Twig - Salix sp. & $*$ & suspect \\
\hline & & & & & & Poz-50224 & 5570 & 40 & 6291 & 6434 & 685 & Twigs undiff & $*$ & \\
\hline & & & & & & Poz-50222 & 6040 & 40 & 6784 & 6996 & 708 & Twig of deciduous tree & $*$ & \\
\hline & & & & & & Poz-50228 & 6660 & 40 & 7461 & 7594 & 743 & Herbaceous fragments & $*$ & \\
\hline & & & & & & Poz-50229 & 7670 & 50 & 8385 & 8552 & 807 & Twig of deciduous tree & $*$ & \\
\hline & & & & & & Poz-50221 & 8090 & 80 & 8663 & 9274 & 832 & Bark of conifer and twig & $*$ & \\
\hline & & & & & & Poz-46762 & 8050 & 50 & 8725 & 9090 & 865.5 & Twig of deciduous tree & $*$ & \\
\hline & & & & & & Poz-50225 & 8820 & 50 & 9686 & 10,155 & 963 & Twig undiff & $*$ & \\
\hline & & & & & & Poz-46757 & 9380 & 50 & 10,442 & 10,734 & 1038 & Herbaceous fragment & $*$ & \\
\hline & & & & & & Poz-49768 & 8930 & 50 & 9904 & 10,214 & 1140 & Vegetal debris undiff & $*$ & suspect \\
\hline \multirow[t]{4}{*}{9} & Fate & 44.14 & 7.05 & 2130 & $\mathrm{E}$ & Ly1597 & 6480 & 100 & 7179 & 7572 & 133 & Alnus sp. & -28.03 & \\
\hline & $-b, c$ & & & & & Ly1596 & 8850 & 60 & 9704 & 10,172 & 141 & Salix sp. & 28.45 & \\
\hline & & & & & & Ly1595 & 9300 & 60 & 10,283 & 10,658 & 171 & Salix sp. & -27.92 & \\
\hline & & & & & & Ly1594 & 9660 & 60 & 10,779 & 11,205 & 214 & Salix sp. & $*$ & \\
\hline \multirow[t]{2}{*}{15} & Grenouilles & 44.05 & 7.29 & 1990 & SE & Gif-10370 & 1720 & 40 & 1545 & 1715 & 80 & Peat & -26.75 & \\
\hline & $-d$ & & & & & Gif-10371 & 4700 & 60 & 5316 & 5583 & 170 & Peat & -25.88 & \\
\hline \multirow[t]{4}{*}{2} & Lauzanier & 44.22 & 6.52 & 2310 & $\mathrm{~N}$ & Poz-18882 & 2660 & 35 & 2744 & 2844 & 31 & Peat & $*$ & \\
\hline & -e & & & & & Poz-18884 & 3655 & 35 & 3886 & 4087 & 54 & Wood & $*$ & \\
\hline & & & & & & Poz-18883 & 9460 & 50 & 10,567 & 11,068 & 79 & Bulk sediment (gyttja) & $*$ & \\
\hline & & & & & & Poz-18885 & 12,180 & 60 & 13,835 & 14,241 & 116 & Bulk sediment (clay) & * & suspect \\
\hline \multirow[t]{18}{*}{7} & Long Inférieur & 44.03 & 7.27 & 2090 & $\mathrm{E}$ & Ly1244 & 2660 & 190 & 2322 & 3321 & IC & * & $*$ & \\
\hline & $-f, g, h$ & & & & & Ly1243 & 3740 & 160 & 3643 & 4528 & IC & * & $*$ & \\
\hline & & & & & & Ly1242 & 4770 & 300 & 4651 & 6205 & IC & * & * & \\
\hline & & & & & & Ly1241 & 5670 & 170 & 6023 & 6887 & IC & $*$ & $*$ & \\
\hline & & & & & & AA_36512 & 5678 & 50 & 6321 & 6628 & 138 & Bulk sediment (gyttja) & -25.4 & \\
\hline & & & & & & AA_36513 & 8087 & 58 & 8772 & 9246 & 290 & Bulk sediment (gyttja) & -24.6 & \\
\hline & & & & & & AA_36514 & 8692 & 53 & 9540 & 9886 & 328 & Bulk sediment (gyttja) & -25 & \\
\hline & & & & & & AA_36515 & 8801 & 54 & 9627 & 10,152 & 358 & Bulk sediment (gyttja) & -24.6 & \\
\hline & & & & & & Ly1207 & 10,430 & 210 & 11,410 & 12,724 & IC & * & $*$ & \\
\hline & & & & & & AA_36516 & 10,892 & 80 & 12,685 & 12,977 & 482 & Bulk sediment & -22.4 & \\
\hline & & & & & & Ly1206 & 10,970 & 210 & 12,435 & 13,281 & IC & $*$ & $*$ & \\
\hline & & & & & & AA_36517 & 11,263 & 82 & 12,977 & 13,299 & 488 & Bulk sediment (clay) & -21.3 & \\
\hline & & & & & & AA_36518 & 11,720 & 79 & 13,413 & 13,741 & 511 & Bulk sediment (clay) & -20.3 & \\
\hline & & & & & & Ly1205 & 12,040 & 370 & 13,166 & 15,184 & IC & * & $*$ & suspect \\
\hline & & & & & & Ly1237 & 12,170 & 280 & 13,473 & 15,115 & IC & $*$ & $*$ & suspect \\
\hline & & & & & & Ly1236 & 12,510 & 370 & 13,619 & 15,847 & IC & $*$ & $*$ & suspect \\
\hline & & & & & & Ly1235 & 13,460 & 410 & 15,015 & 17,477 & IC & $*$ & $*$ & suspect \\
\hline & & & & & & AA_36519 & 14,190 & 130 & 16,860 & 17,635 & 558 & Bulk sediment (clay) & -16.7 & suspect \\
\hline \multirow[t]{4}{*}{14} & Mouton & 44.03 & 7.26 & 2175 & $\mathrm{E}$ & Ly1247 & 3000 & 160 & 2784 & 3555 & 60 & $*$ & $*$ & \\
\hline & $-f$ & & & & & Ly1248 & 8220 & 200 & 8609 & 9540 & 115 & $*$ & $*$ & \\
\hline & & & & & & Ly1249 & 7930 & 170 & 8409 & 9254 & 125 & $*$ & $*$ & \\
\hline & & & & & & Ly1246 & 9340 & 240 & 9917 & 11,230 & 205 & $*$ & $*$ & \\
\hline \multirow[t]{5}{*}{8} & Orgials & 44.12 & 7.08 & 2240 & SW & Ly1599 & 1875 & 35 & 1719 & 1885 & 59 & Vegetal debris & -28.26 & \\
\hline & $-b, c$ & & & & & Poz-7107 & 4670 & 35 & 5314 & 5571 & 142 & Bulk sediment (gyttja) & $*$ & \\
\hline & & & & & & Poz-7108 & 7820 & 40 & 8479 & 8721 & 234 & Bulk sediment (gyttja) & $*$ & \\
\hline & & & & & & Ly1611 & 9783 & 68 & 10,874 & 11,349 & 359 & Bryophyts & $*$ & \\
\hline & & & & & & Ly1598 & 20,930 & 130 & 24,850 & 25,631 & 406 & Bryophyts & $*$ & suspect \\
\hline \multirow[t]{7}{*}{16} & Petit & 44.06 & 7.11 & 2225 & $\mathrm{~S}$ & Poz-32578 & 1240 & 40 & 1069 & 1271 & 26 & Terrestrial debris & $*$ & \\
\hline & $-i, j$ & & & & & Poz-39213 & 1720 & 30 & 1559 & 1702 & 39 & Wood - Larix & $*$ & \\
\hline & & & & & & Poz-355509 & 1890 & 30 & 1735 & 1893 & 58 & Wood - Conifer & $*$ & \\
\hline & & & & & & Poz-32576 & 3620 & 40 & 3835 & 4080 & 94 & Terrestrial debris & $*$ & \\
\hline & & & & & & Poz-35507 & 3855 & 35 & 4156 & 4410 & 111 & Bark - Conifer & $*$ & \\
\hline & & & & & & Poz-39212 & 4125 & 35 & 4528 & 4820 & 135 & Twig - Ericaceae & $*$ & \\
\hline & & & & & & Poz-32577 & 4110 & 35 & 4455 & 4818 & 137 & Twigs framents & $*$ & \\
\hline 4 & $\begin{array}{l}\text { Restefond } \\
-\mathrm{k}\end{array}$ & 44.19 & 6.47 & 2400 & SW & & & & & & & & & \\
\hline 11 & Rifugo Mondovi & 44.11 & 7.44 & 1760 & $\mathrm{~S}$ & Ly1606 & 965 & 45 & 785 & 960 & 140 & Peat & -29.5 & \\
\hline & $-b, c$ & & & & & Ly1607 & 1825 & 50 & 1620 & 1875 & 210 & Peat & -27.35 & \\
\hline
\end{tabular}


Table 2 (continued)

\begin{tabular}{|c|c|c|c|c|c|c|c|c|c|c|c|c|c|c|}
\hline Code & $\begin{array}{l}\text { Name and } \\
\text { reference }\end{array}$ & $\begin{array}{l}\text { Lat } \\
(\mathrm{N})\end{array}$ & $\begin{array}{l}\text { Long } \\
\text { (E) }\end{array}$ & $\begin{array}{l}\text { Altitude } \\
\text { (m asl) }\end{array}$ & Aspect & $\begin{array}{l}\text { Sample } \\
\text { code }\end{array}$ & $\begin{array}{l}{ }^{14} \mathrm{C} \text { age } \\
\text { uncal. BP }\end{array}$ & $\begin{array}{l}\text { Error } \\
(2 \sigma)\end{array}$ & $\begin{array}{l}\text { Min cal. } \\
\operatorname{BP}(2 \sigma)\end{array}$ & $\begin{array}{l}\text { Max cal. } \\
\operatorname{BP}(2 \sigma)\end{array}$ & $\begin{array}{l}\text { Core } \\
\text { depth } \\
(\mathrm{cm})\end{array}$ & Material & $\delta^{13} \mathrm{C}$ & Remark \\
\hline & & & & & & Ly10757 & 1965 & 55 & 1741 & 2060 & 260 & Peat & -28.68 & \\
\hline & & & & & & Ly10758 & 2575 & 60 & 2442 & 2837 & 290 & Peat & -28.67 & \\
\hline & & & & & & Ly10759 & 5725 & 90 & 6315 & 6718 & 370 & Peat & -28.02 & \\
\hline & & & & & & Ly1608 & 9790 & 60 & 11,094 & 11,327 & 390 & Peat & -28.99 & \\
\hline \multirow[t]{2}{*}{13} & Sabion & 44.07 & 7.28 & 2215 & $S$ & Ly1145 & 10,380 & 400 & 10,870 & 13,063 & 245 & $*$ & $*$ & suspect \\
\hline & $-\mathrm{f}$ & & & & & Ly1146 & 9340 & 450 & 9475 & 12,005 & 255 & $*$ & * & \\
\hline 5 & $\begin{array}{l}\text { Terres Plaines } \\
-\mathrm{k}\end{array}$ & 44.2 & 6.45 & 2100 & $\mathrm{~N}$ & & & & & & & & & \\
\hline \multirow[t]{2}{*}{6} & Vallon de Provence & 44.23 & 6.24 & 2075 & $\mathrm{NE}$ & Ly731 & 9900 & 90 & 11,179 & 11,709 & 435 & $*$ & * & \\
\hline & & & & & & Ly730 & 11,510 & 140 & 13,074 & 13,592 & 470 & * & * & \\
\hline 3 & $\begin{array}{l}\text { Vallon du Loup } \\
-1\end{array}$ & 44.24 & 6.24 & 2010 & $\mathrm{NE}$ & & & & & & & & & \\
\hline \multirow[t]{2}{*}{12} & Vei del Bouc & 44.08 & 7.25 & 2055 & $\mathrm{~N}$ & Ua-16175 & 5745 & 90 & 6321 & 6739 & 161 & Salix sp. & -26.4 & \\
\hline & $-m, n$ & & & & & Ua-16176 & 7525 & 90 & 8169 & 8536 & 171 & Pinus cembra & -24 & \\
\hline \multirow[t]{29}{*}{10} & Vens & 44.18 & 6.56 & 2330 & NW & SacA-31217 & 355 & 45 & 312 & 498 & 37 & Coleoptera & -12.3 & \\
\hline & -this study & & & & & SacA-28193 & 300 & 30 & 296 & 460 & 42 & Leaf & -28.5 & \\
\hline & & & & & & SacA-22282 & 470 & 30 & 494 & 540 & 68 & Vegetal debris undiff (VENO9P3) & -25.1 & suspect \\
\hline & & & & & & SacA-31697 & 2700 & 35 & 2753 & 2859 & 77 & Pollen extract & -28.8 & rejected \\
\hline & & & & & & SacA-31719 & 2735 & 30 & 2763 & 2917 & 105 & Pollen extract & -27.9 & rejected \\
\hline & & & & & & SacA-22283 & 435 & 30 & 338 & 531 & 139 & Vegetal debris undiff (VEN09P3) & -26 & rejected \\
\hline & & & & & & Poz-34153 & 1155 & 30 & 982 & 1175 & 139 & Vegetal debris undiff (VEN09P3) & * & suspect \\
\hline & & & & & & SacA-31720 & 2250 & 35 & 2154 & 2345 & 140 & Coleoptera and pollen extract & -27.2 & rejected \\
\hline & & & & & & Poz-48423 & 2525 & 35 & 2490 & 2745 & 168 & Pollen extract & * & rejected \\
\hline & & & & & & SacA-22284 & 2470 & 30 & 2380 & 2717 & 197 & Vegetal debris undiff (VEN09P3) & -25.1 & rejected \\
\hline & & & & & & Poz-48424 & 3315 & 35 & 3458 & 3632 & 201 & Pollen extract & * & rejected \\
\hline & & & & & & Poz-48425 & 3370 & 40 & 3482 & 3700 & 252 & Coleoptera and pollen extract & * & rejected \\
\hline & & & & & & SacA-31721 & 3565 & 30 & 3726 & 3968 & 278 & Twig of conifer & -32 & rejected \\
\hline & & & & & & Poz-40617 & 3040 & 35 & 3157 & 3358 & 280 & Scale - Conifer undiff & * & \\
\hline & & & & & & SacA-31722 & 2960 & 30 & 3005 & 3211 & 283 & Scale - Conifer undiff & -27.6 & \\
\hline & & & & & & SacA-28194 & 3990 & 30 & 4415 & 4523 & 301 & Needle - Abies sp. & -24.5 & \\
\hline & & & & & & SacA-28195 & 4165 & 30 & 4583 & 4829 & 309 & scale - Conifer undiff & -25.7 & \\
\hline & & & & & & Poz-48426 & 4390 & 35 & 4859 & 5210 & 317 & Twig - Pinus sp. & * & \\
\hline & & & & & & SacA-28196 & 5380 & 35 & 6017 & 6282 & 334 & Charcoal of wood & -21.5 & \\
\hline & & & & & & SacA-28197 & 8080 & 40 & 8781 & 9127 & 364 & Twig - Alnus sp. & -24 & rejected \\
\hline & & & & & & SacA-31723 & 6200 & 35 & 6997 & 7240 & 368 & Twig - Alnus sp. & -28.3 & \\
\hline & & & & & & Poz-40618 & 9410 & 50 & 10,512 & 10,755 & 393 & Wood of Betula sp. & * & rejected \\
\hline & & & & & & SacA-28198 & 8295 & 50 & 9130 & 9438 & 408 & Twig - Conifer undiff & -20 & \\
\hline & & & & & & SacA-28199 & 8135 & 35 & 8999 & 9241 & 412 & Twig - Alnus sp. & -27.3 & \\
\hline & & & & & & Poz-40619 & 8660 & 40 & 9539 & 9696 & 418 & Wood - Salix sp. & $*$ & \\
\hline & & & & & & SacA-31724 & 10,660 & 70 & 12,434 & 12,724 & 450 & Pollen extract & -30.1 & rejected \\
\hline & & & & & & SacA-31725 & 9900 & 50 & 11,208 & 11,599 & 496 & Pollen extract & -31.8 & suspect \\
\hline & & & & & & SacA-31726 & 13,630 & 70 & 16,188 & 16,712 & 569 & Pollen extract & -28.6 & rejected \\
\hline & & & & & & SacA-28200 & 13,900 & 70 & 16,548 & 17,102 & 705 & Pollen extract & -26.4 & rejected \\
\hline
\end{tabular}

glacial deposits, we suppose that they could be remnants of UED-I. Slight discrepancies between elevation and the corresponding $\delta E L A$ of these stages through the Mediterranean Alps could be attributed to particular geomorphological and topography-influenced climate conditions and to the different methods used (Höfer method in UED and FMA and the Balance ratio method in IMA). Overall, these oldest Lateglacial stages can be considered as short glacier stagnations or moderate re-advances in a general and rapid melting since the LGM. These stages correspond obviously to minor cooling occurring during the GS-2a period after the glacial maximum dated at 20,000-23,000 cal. BP (GS-2b period). Following Jorda and Rosique (1994), this review emphasizes the rapidity of glacial retreat from the near maximal extension of glacial tongues downstream in the valley to the upper cirques above 2000 or $2300 \mathrm{~m}$ a.s.l. before $14,500 \mathrm{cal}$. BP, in less than 7 millennia. This time interval may be shorter in the IMA in the Gesso valley where Federici et al. (2012) have recently provided a ${ }^{10} \mathrm{Be}$ age ranging from $16,590 \pm 970$ to $18,200 \pm 1060$ years from the Gschnitz stadial of the Alpine Lateglacial chronology, associated with Heinrich Event 1 from a frontal moraine ridge situated at $850 \mathrm{~m}$ a.s.l. Therefore, in this valley, the moraine ridge IMA-I, located at $2050 \mathrm{~m}$ a.s.l. under the mire of Vei del Bouc, must have been built during the very end of the GS-2a period.
7.4.1.3. Younger Dryas and Holocene glacial deposits and major environmental changes recorded by sediment cores. The moraine ridges located above the studied lakes must be related to a cooling period younger than the Bölling-Alleröd. It is highly probable that the glacial deposits situated immediately above the lakes correspond to the major cooling occurring after the GI-1a, which is the Younger Dryas. Upvalley, moraine ridges and glacial rocks must be Holocene. This assumption can be comforted by observing lacustrine sediment facies which inform on environmental changes, timing of melting and strength of glacial processes. Fig. 9 shows a simplified lithostratigraphical core description from the 16 representative lakes in the Mediterranean Alps. The sediment cores show three lithotype successions since the Lateglacial.

Lake infilling starts by accumulation of an organic-poor blue clay lithotype (Fig. 9A) often interrupted by sandy layers, characteristic of glacial activity in lake catchments (Fig. 9B, situation 1). At Vens, as in most of the studied lakes of the FMA, IMA and UED, the deposition of a blue clay lithotype covers the Bölling and stops at the end of the YD. These glacio-lacustrine processes could be related with the moraine ridges of Vens-2, FMA-II, IMA-II and UEDIII ( $\delta$ ELA ranging between 350 and $600 \mathrm{~m}$ ). At Vens, the reduced $\delta E L A$ of this moraine ridge is probably due to the very small size of the catchment $\left(4 \mathrm{~km}^{2}\right)$. NGRIP reconstructions (Rasmussen et al., 


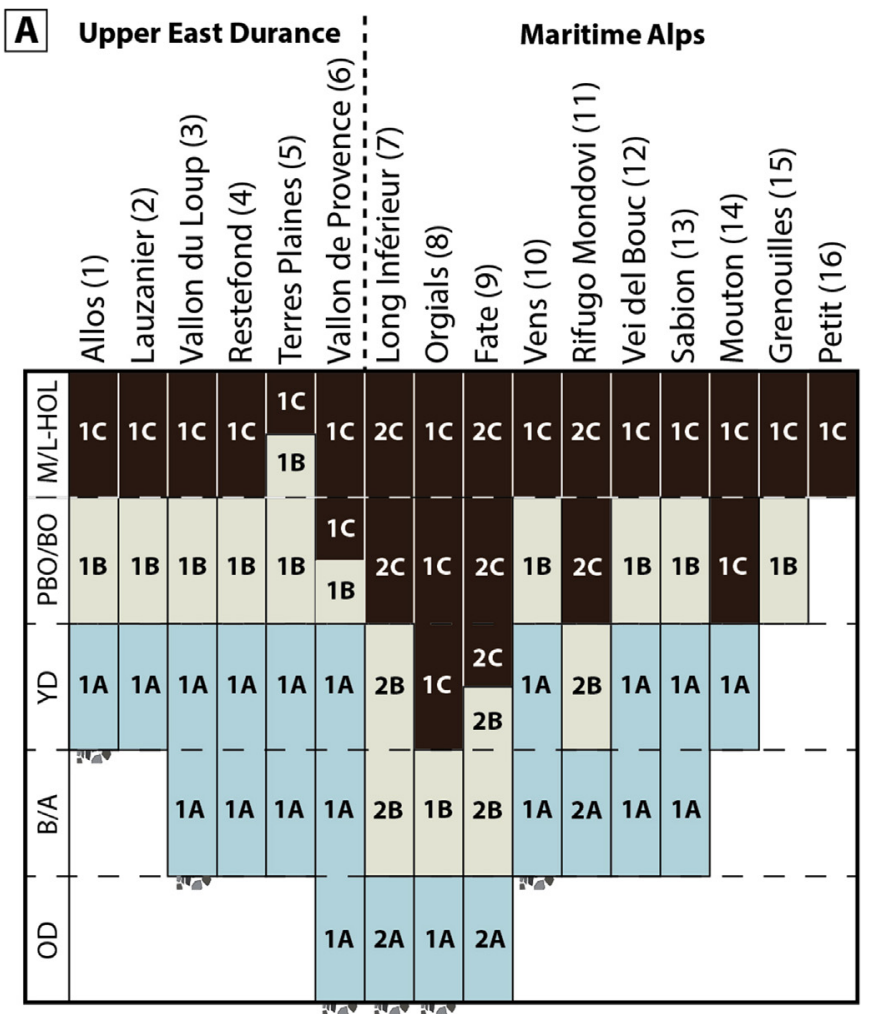

B

\section{Situation 1}

1A-Glacier down to valley floor feeds the lake

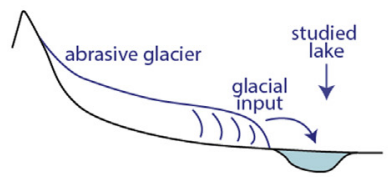

1B-Trend to disapearence of active glacier in cirque

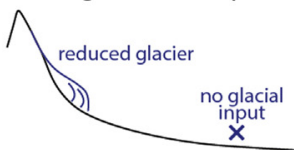

1C-Complete disapearence of active glacier in cirque

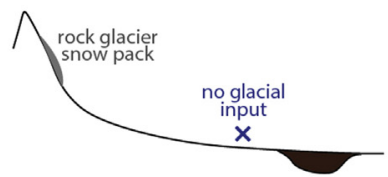

Blue clay, sandy layers $\square$ Beige to light brown silt clay Brown gyttja, peat, organic laminated Morainic debris

Fig. 9. (A) Lithotypes and pollen stratigraphy of lake and mire sediment cores from the Mediterranean Alps (details of individual cores are given in Table 2) and interpretation of lithotype deposition (from $1 \mathrm{~A}$ to $1 \mathrm{C}$ and from $2 \mathrm{~A}$ to $2 \mathrm{C}$ ). (B) Interpretation of lithotypes depends on the geomorphological setting which comprises two different situations. OD: Oldest Dryas, B/A: Bölling-Alleröd, YD: Younger Dryas, PBO/BO: Preboreal/Boreal, M/L HOL: Mid-to Late-Holocene.
2008) suggest minor cooling (GI-1d and GI-1b) during the generally warmer period of the Bölling-Alleröd which could have locally maintained the strong influence of glacier processes until the major cooling event of the YD (GS-1) responsible for the formation of moraine ridges.

The blue clay lithotype is overlain by a beige to light brown lithotype, mainly composed of silt-clay and rarely interrupted by sandy layers, indicating progressive increase in organic matter. This reflects vegetation colonisation and soil development at these altitudes attended by stabilisation of slopes. This phase is constrained by the ${ }^{14} \mathrm{C}$ age corpus between 13,500 and $8700 \mathrm{cal}$. BP. In four lakes (Rifugio Mondovi, Long Inférieur, Fate and Orgials), all located in the Maritime Alps, the accumulation of the blue clay lithotype ends earlier than in the other lakes, and the YD cooling, expressed in all pollen diagrams by the sharp increase in cold steppe herbs, is recorded during deposition of the beige/light brown lithotype. We might suppose that this delay is due to the southern position of the Maritime Alps: warming conditions during the Lateglacial might have been more pronounced than in the northern Alps, explaining lower glacier influence on sediment cores. Moreover, local geomorphological settings could have influenced lacustrine sedimentation. For example, in case of Long Inférieur, Fate and Rifugio Mondovi, the lakes were probably disconnected to direct melting water from the YD glacier and higher lakes could have played a role in buffering sediment supply downstream (Fig. 9B, situation 2).

In all of the 16 lake sequences, light brown deposits are overlain by the dark brown lithotype associated with organic-rich (algal and/or terrestrial) sediment. Persistence of this lithotype toward the top of all cores reflects conditions of non-glaciated catchments throughout the Mid-to Late-Holocene (Fig. 9A and B). The dataset allows constraining of this phase from 11,500 cal. BP to Present, which is supported by the dozen ${ }^{14} \mathrm{C}$ ages encompassing the Holocene period (Table 2). The moraine ridges located above $2400 \mathrm{~m}$ (Vens-III-IV, FMA-III-IV, IMA-III and UED-IV-VI), corresponding to a $\delta$ ELA lower than $350 \mathrm{~m}$, attributed to the Holocene period (to the LIA for the youngest), correspond to glacier readvance that was not sufficient to interrupt the organic-rich sedimentation. These results plead in favour of a debris cover of restricted extent and poorly erosive glaciers during the Late Holocene.

7.4.1.4. Influence of the geographical situation. The datasets have been investigated in terms of geographical settings of major environmental changes in the Mediterranean Alps during the Lateglacial and the Holocene. The classification of lithological information according to altitude is presented in Fig. 10. The insufficient number of ${ }^{14} \mathrm{C}$ ages obtained in the blue clay lithotype does not allow for interpretation in terms of altitude. A more significant criterion could be the distribution of the ${ }^{14} \mathrm{C}$ ages corresponding to the beige to light brown lithotype. The onset of this lithotype occurs 2000 years earlier at an altitude of $2090 \mathrm{~m}$ a.s.l. (13,500 cal. BP at Long Inférieur) compared to Lake Allos at $2250 \mathrm{~m}$ a.s.l. (10,600 cal. BP). A similar pattern may be noticed for the beginning of the dark brown organic-rich lithotype which appears ca 2000 years earlier at a site located below $2200 \mathrm{~m}$ a.s.l. (11,000 cal. BP), than in lakes located between 2200 and $2400 \mathrm{~m}$ a.s.l. (9000 cal. BP). Therefore, even if the datasets provide an incomplete image of the numerous small catchments of the area, the effect of the altitudinal factor on the timing of major environmental changes might be interpreted, characterized by a time lag of roughly 2000 years depending on whether catchments are located below or above $2200 \mathrm{~m}$ a.s.l. Fig. 10 presents a sorting of lithological information according to cirque exposure. Lake catchment exposure seems to have an effect on the timing of the onset of the beige to light brown lithotype, as well as on the onset of the dark brown organic-rich lithotype. The onset of 
northeast Italy, at 21,000 cal. BP in the Italian Apennines (Giraudi and Frezzotti, 1997), and at 18,000-17,000 cal. BP in the northern Switzerland (Reitner, 2007). Since the northern Alps experienced a cirque glacier phase that started during the Bölling (Van Husen, 1997; Ohlendorf, 1998), these data plead for a rapid decay of the ice body at the end of the last glaciation in the Alps (Ivy-Ochs et al., 2008) as well in the Mediterranean Alps.

Consecutive to lake formation, the deglaciation of cirque glaciers in the Mediterranean Alps is interrupted by modest re-advances (Giraudi and Frezzotti, 1997) and the lowest moraine is probably related to the YD. Glacial forms of the YD are abundant in the Alpine chain (Egesen stadial) and exposure ages are consistent, giving ages comprised between 12,300 and 10,800 ${ }^{10}$ Be years (Kelly et al., 2004; Federici et al., 2008; Hormes et al., 2008; Ivy-Ochs et al., 2009; Cossart et al., 2012; Darnault et al., 2012). In each case, glacier advance during the YD exclusively affects upper catchments. On the basis of difference in equilibrium line altitude between the YD moraines, Federici et al. (2008) suggest that humid conditions comparable to those on the northern slopes of the Alps (Kerschner and Ivy-Ochs, 2008) prevailed in Mediterranean Maritime Alps.

The onset of increase in the organic-rich unit is also recognised in sediment cores of numerous high-altitude lakes in the Alps (Koinig et al., 2003; Mourier et al., 2010; Giguet-Covex et al., 2011; Thevenon et al., 2012). This gyttja facies is always associated with afforestation of cirque catchments (e.g., Ponel et al., 2001; Finsinger and Tinner, 2007), timberline increase (Nicolussi et al., 2005) and soil development (Favilli et al., 2009; Böhlert et al., 2011). Organicrich sediment dominates lake infilling since ca 11,000 cal. BP in the Mediterranean Alps whereas the onset of this facies is dated between 10,000 and 9000 cal. BP in the northern and eastern Alps. In the northern Alps, short glacier re-advances occurred at 11,500 and $10,000{ }^{10}$ Be years (Ivy-Ochs et al., 2009). Even if regional comparisons of the timing of the onset of sedimentation are speculative due to the prerequisite of larger-scale sediment core syntheses, we propose that the imprint of glaciers during the Preboreal oscillation might have been more important - and possibly colder - in the northern Alps (especially in north-facing catchments), thus explaining the time lag of ca 1000 years between the Southern and Northern Alps.

During the Mid-to Late-Holocene, glacier advances smaller than those than prior to $10,000 \mathrm{cal}$. BP are observed in the northern Alps (Joerin et al., 2008; Goehring et al., 2012). Even if mass balance was positive to maintain small glaciers, Ivy-Ochs et al. (2009) suggest there were no time windows long enough to permit their development. This could explain the continuous organic-rich facies observed in lake sediments of the Mediterranean Alps over this period. Nevertheless, even if rock glacier activities in the Mediterranean Alps are recorded at 2720-2360 cal. BP and then during the Little Ice Age (Federici and Stefanini, 2001; Ribolini et al., 2007), which denotes similarities to the glacial record of the northern Alps (Ivy-Ochs et al., 2009), they did not induce change in sediment facies. Hence, we suggest that although a shift to climatic conditions more favourable to glacier formation (generally colder, and less frequent warm periods) may have occurred, this was not sufficient to induce a reversal in the overall ecosystem expansion in the Mediterranean Alps initiated 10,000 years ago. More so than climatic change, anthropogenic pressure is probably the main driver of ecosystem destabilisation during the Holocene. This is underlined by the concomitance between the increase in anthropogenic pressure and that of sedimentation rate recorded in Lake Vens over the last 1800 years, whereas intense rock glacier activity attesting to a cooling trend was detected 500-1000 years before in the neighbouring valley (Ribolini et al., 2007).

\section{Conclusion}

A corpus of sedimentological, palynological and chronological data from 16 lake sediment sequences occupying high-altitude cirques in the Mediterranean Alps provides a maximum age of 14,500 cal. BP for glacier tongue retreat above $2000 \mathrm{~m}$ a.s.l based on palynostratigraphical events. The first relevant ${ }^{14} \mathrm{C}$ age supporting independently the chronology of an ice-free lake bottom is age of $13,740-13,410 \mathrm{cal}$. BP. Thus deglaciation of the main valley tongues occurred before the Bölling interstadial (GI-1e).

The compilation of sediment cores indicates three units, starting, from bottom to top, by organic-poor blue clay, beige to light brown silt clay and a dark brown and organic-rich lithotype. The review is supported by analyses of the Lake Vens sequence, which offers a good example of these major lithotype alternations. The last stages of domination of glacier processes are evidenced by a lithotype transition from blue clay to beige silt at the end of the Younger Dryas chronozone. Thus, the Younger Dryas glacier advance did not attain the altitude of lakes situated in the French Maritime Alps, stage II in the French Maritime Alps (FMA-II) and stage III in the Upper Eastern Durance (UED-III) are attributed to this phase. The Younger Dryas stadial in the Mediterranean Alps is consistent with the Egesen stadial of the northern Alps.

Progressive increase in organic matter in sediment cores suggests stabilisation of slopes during broadleaved tree afforestation and soil formation during the Preboreal. From 13,000 to $8700 \mathrm{cal}$. BP, changes in lake sediment are signs of a declining influence of glacial processes and the progressive dominance of biogenic processes. The onset of dark brown and organic-rich sediment deposition at ca 11,500 cal. BP takes place during the Holocene climatic optimum. An altitudinal and an exposure gradient could explain the time lag of 2000 years for the onset of the major environmental changes.

Our synthesis provides an indirect record of the final stages of glacier activity in the cirque. Lake sediments offer a large corpus of data, often composed of sedimentological descriptions, palynological diagrams and ${ }^{14} \mathrm{C}$ ages. Even if radiocarbon ages need to be examined with caution, these multiproxy analyses are valuable as independent arguments regarding the chronology and dynamics of palaeoenvironmental changes. Multi-proxy investigations of direct (absolute dating of frontal moraines) and indirect archives (sediment cores), with a more representative geographic coverage, would probably offer perspectives for clearly elucidating the relationships between major climatic events, glacier fluctuations and environmental responses.

\section{Acknowledgement}

Coring of Lake Vens was rendered possible with the help of the C2FN structure, Geoazur internal BQR, B. Wilhelm, Y. Rolland and R. Darnault and the refuge of Vens. We thank T. Kasper, M. Magny, J. Petersen and two anonymous reviewers for stimulating discussions and advice in improving our manuscript. Radiocarbon ages were obtained through the Artemis French AMS ${ }^{14} \mathrm{C}$ dating Programme and the Poznan Radiocarbon Laboratory. Pollen analyses were funded by the Research Federation ECCOREV. Consultation of original pollen data was rendered possible by the European Pollen Database (M. Leydet). The PhD thesis of E. Brisset has been funded by the Région PACA (France).

\section{Appendix A. Supplementary data}

Supplementary data related to this article can be found at http:// dx.doi.org/10.1016/j.quascirev.2014.12.004. 


\section{References}

Alley, R.B., Marotzke, J., Nordhaus, W.D., Overpeck, J.T., Peteet, D.M., Pielke, R.A., Pierrehumbert, R.T., Rhines, P.B., Stocker, T.F., Talley, L.D., Wallace, J.M., 2003. Abrupt climate change. Science 299, 2005-2010. http://dx.doi.org/10.1126/ science. 1081056.

Ammann, B., Birks, H.H., Walanus, A., Wasylikowa, K., 2007. Plant macrofossil records | late glacial multidisciplinary studies. In: Elias, Scott A. (Ed.), Encyclopedia of Quaternary Science. Elsevier, Oxford, pp. 2475-2486. http://www.scie ncedirect.com/science/article/pii/B0444527478002234.

Begin, J., 1990. Contexte géologique et géomorphologique de la région du Mont Bégo. Répartition des gravures rupestres de l'Age du Bronze dans le site. (Unpublished thesis), Mus. d'Hist Nat.

Bennett, K.D., 1996. Determination of the number of zones in a biostratigraphical sequence. New Phytol. 132, 155-170. http://dx.doi.org/10.1111/j.14698137.1996.tb04521.x.

Beug, H.J., 1975. Mas as a factor in the vegetational history of the Balkan peninsula. Probl. Balkan Flora a. Vegetation, pp. 72-77.

Bigot-Cormier, F., Braucher, R., Bourlès, D., Guglielmi, Y., Dubar, M., Stéphan, J.-F., 2005. Chronological constraints on processes leading to large active landslides. Earth Planet. Sci. Lett. 235, 141-150. http://dx.doi.org/10.1016/ j.epsl.2005.03.012.

Birks, H.J.B., Line, J.M., 1992. The use of rarefaction analysis for estimating palynological richness from quaternary pollen-analytical data. Holocene 2, 1-10. http://dx.doi.org/10.1177/095968369200200101.

Björck, S., Wohlfarth, B., 2001. 14C chronostratigraphic techniques in paleolimnology. In: Last, Smol (Eds.), Tracking Environmental Change Using Lake Sediments, pp. 205-282.

Blaauw, M., 2010. Methods and code for "classical" age-modelling of radiocarbon sequences. Quat. Geochronol. 5, 512-518. http://dx.doi.org/10.1016/ j.quageo.2010.01.002.

Blockley, S.P.E., Lane, C.S., Hardiman, M., Rasmussen, S.O., Seierstad, I.K., Steffensen, J.P., Svensson, A., Lotter, A.F., Turney, C.S.M., Bronk Ramsey, C., 2012. Synchronisation of palaeoenvironmental records over the last 60,000 years, and an extended INTIMATE event stratigraphy to 48,000 b2k. Quat. Sci. Rev. 36, 2-10. http://dx.doi.org/10.1016/j.quascirev.2011.09.017.

Böhlert, R., Mirabella, A., Plötze, M., Egli, M., 2011. Landscape evolution in Val Mulix, eastern Swiss Alps - soil chemical and mineralogical analyses as age proxies. CATENA 87, 313-325. http://dx.doi.org/10.1016/j.catena.2011.06.013.

Bottema, S., 1980. On the history of the wallnut (Juglans regia L.) in southeastern Europe. Acta bot. neerl. 343-349.

Brisset, E., Guiter, F., Miramont, C., Delhon, C., Arnaud, F., Disnar, J.-R., Poulenard, J., Anthony, E., Meunier, J.-D., Wilhelm, B., Pailles, C., 2012. Approche multidisciplinaire d'une séquence lacustre holocène dans les alpes du sud au Lac Petit (Mercantour, alt. $2200 \mathrm{~m}$, France): histoire d'un géosystème dégradé. Quat. Rev. l'Assoc. fr. l'étude Quat. 23, 309-319. http://dx.doi.org/10.4000/ quaternaire.6390.

Brisset, E., Miramont, C., Guiter, F., Anthony, E.J., Tachikawa, K., Poulenard, J., et al., 2013. Non-reversible geosystem destabilisation at 4200 cal. BP: sedimentological, geochemical and botanical markers of soil erosion recorded in a Mediterranean alpine lake. Holocene 23 (12), 1863-1874. http://dx.doi.org/10.1177/ 0959683613508158.

Brisset, E., Miramont, C., Guiter, F., Arnaud, F., Anthony, E., Delhon, C., Guibal, F., Cartier, R., Poher, Y., Chaumillon, E., 2014. Données nouvelles sur la chronologie de la déglaciation dans la vallée du Haut Verdon (Lac d'Allos, Alpes Françaises du Sud). Quaternaire 25 (2), 145-153. http://quaternaire.revues.org/7028.

Brugiapaglia, E., 1996. Dynamique de la végétation Tardiglaciaire et Holocène dans les Alpes italiennes nord-occidentales (PhD thesis). Aix-Marseille Université III.

Carrion, J.S., Sanchez-Gomez, P., 1992. Palynological data in support of the survival of Walnut (Juglans regia L.) in the western mediterranean area during last glacial times. J. Biogeogr. 19, 623. http://dx.doi.org/10.2307/2845705.

Clerc, J., 1988. Recherches pollenanalytiques sur la paléoécologie tardiglaciaire et holocène du Bas-Dauphiné. Aix-Marseille Université III.

Conedera, M., Krebs, P., Tinner, W., Pradella, M., Torriani, D., 2004. The cultivation of Castanea sativa (Mill.) in Europe, from its origin to its diffusion on a continental scale. Veg. Hist. Archaeobot. 13, 161-179. http://dx.doi.org/10.1007/s00334004-0038-7.

Cossart, E., Fort, M., Bourlès, D., Braucher, R., Perrier, R., Siame, L., 2012. Deglaciation pattern during the Lateglacial/Holocene transition in the southern French Alps. Chronological data and geographical reconstruction from the Clarée Valley (upper Durance catchment, southeastern France). Palaeogeogr. Palaeoclimatol. Palaeoecol. 315-316, 109-123.

Court-Picon, M., 2007. Mise en place du paysage dans un milieu de moyenne et haute moyenne du tardiglaciaire à l'époque actuelle ( $\mathrm{PhD}$ thesis). Université de Franche-Comté.

Darnault, R., Rolland, Y., Braucher, R., Bourlès, D., Revel, M., Sanchez, G., Bouissou, S., 2012. Timing of the last deglaciation revealed by receding glaciers at the Alpine-scale: impact on mountain geomorphology. Quat. Sci. Rev. 31, 127-142. http://dx.doi.org/10.1016/j.quascirev.2011.10.019.

David, F., 1993. Evolution de la limite supérieure des arbres dans les Alpes françaises du Nord depuis la fin des temps glaciaires ( $\mathrm{PhD}$ thesis). Aix-Marseille Université III.

David, F., Farjanel, G., Jolly, M.P., 2001. Palyno- and chronostratigraphy of a long sequence from Lac d'Annecy (northern outer Alps, France). J. Paleolimnol. 25, 259-269. http://dx.doi.org/10.1023/A:1008142810171. e Beaulieu, J.-L., 1977. Contribution pollenanalytique à l'histoire tardiglaciaire et Holocène de la végétation des Alpes méridionales françaises ( $\mathrm{PhD}$ thesis). AixMarseille Université.

Digerfeldt, G., de Beaulieu, J.-L., Guiot, J., Mouthon, J., 1997. Reconstruction and paleoclimatic interpretation of Holocene lake-level changes in Lac de SaintLéger, Haute-Provence, southeast France. Palaeogeogr. Palaeoclimatol. Palaeoecol. 136, 231-258. http://dx.doi.org/10.1016/S0031-0182(97)00075-8.

Dijkstra, T.A., Janssen, C.R., Middelkoop, H., Salomé, A.I., 1990. Observations concerning the extent and chronology of the Late-Glacial déglaciation stages in the Southern French Alps on the basis of two pollen diagrams. Quaternaire 1, 123-137. http://dx.doi.org/10.3406/quate.1990.1929.

Dubar, M., Anthony, E.J., 1995. Holocene Environmental Change and River-Mouth Sedimentation in the Baie des Anges, French Riviera. Quat. Res. 43, 329-343. http://dx.doi.org/10.1006/qres.1995.1039.

Dubar, M., Poizat, M., 1976. Le glaciaire de la vallée des Merveilles (Alpes-Maritimes). Nice, France.

Durand, Y., Giraud, G., Laternser, M., Etchevers, P., Mérindol, L., Lesaffre, B., 2009. Reanalysis of 47 Years of climate in the French Alps (1958-2005): climatology and trends for snow cover. J. Appl. Meteorol. Climatol. 48, 2487-2512. http:// dx.doi.org/10.1175/2009JAMC1810.1.

Egli, M., Brandová, D., Böhlert, R., Favilli, F., Kubik, P.W., 2010. 10Be inventories in Alpine soils and their potential for dating land surfaces. Geomorphology 119, 62-73. http://dx.doi.org/10.1016/j.geomorph.2010.02.019.

Favilli, F., Egli, M., Brandova, D., Ivy-Ochs, S., Kubik, P., Cherubini, P., Mirabella, A., Sartori, G., Giaccai, D., Haeberli, W., 2009. Combined use of relative and absolute dating techniques for detecting signals of Alpine landscape evolution during the late Pleistocene and early Holocene. Geomorphology 112, 48-66. http:// dx.doi.org/10.1016/j.geomorph.2009.05.003.

Feagri, K., Iversen, J., 1975. Text Book of Pollen Analysis. Blackwell, Oxford.

Federici, P.R., Stefanini, M.C., 2001. Evidences and chronology of the Little Ice Age in the Argenterra Massif (Italian Maritime Alps). Z. Gletscherkd. Glazialgeol. 37, 35-48.

Federici, P.R., Pappalardo, M., Ribolini, A., 2003. Geomorphological Map of the Maritime Alps Natural Park (Argentera Massif, Italy) and Surroundings. S.EL.CA., Firenze.

Federici, P.R., Granger, D.E., Pappalardo, M., Ribolini, A., Spagnolo, M., Cyr, A.J., 2008. Exposure age dating and Equilibrium Line Altitude reconstruction of an Egesen moraine in the Maritime Alps, Italy. Boreas 37, 245-253. http://dx.doi.org/ 10.1111/j.1502-3885.2007.00018.x.

Federici, P.R., Granger, D.E., Ribolini, A., Spagnolo, M., Pappalardo, M., Cyr, A.J., 2012. Last Glacial Maximum and the Gschnitz stadial in the Maritime Alps according to 10Be cosmogenic dating. Boreas 41, 277-291. http://dx.doi.org/10.1111/ j.1502-3885.2011.00233.x.

Finsinger, W., 2001. Vegetation history and human impact at the Lago del Vei del Bouc (Argentera Massif, Maritime Alps)/Histoire de la végétation et de l'impact de l'homme au Lago del Vei del Bouc (Massif de l'Argentera, Alpes-Maritimes). Quaternaire 12, 223-233. http://dx.doi.org/10.3406/quate.2001.1695.

Finsinger, W., Ribolini, A., 2001. Late glacial to Holocene deglaciation of the Colle del Vei del Bouc-Colle del Sabbione Area (Argentera Massif, Maritime Alps, ItalyFrance). Geogr. Fis. Din. Quat. 24, 141-156.

Finsinger, W., Tinner, W., van der Knaap, W.O., Ammann, B., 2006. The expansion of hazel (Corylus avellana L.) in the southern Alps: a key for understanding its early Holocene history in Europe? Quat. Sci. Rev. 25, 612-631. http://dx.doi.org/ 10.1016/j.quascirev.2005.05.006.

Finsinger, W., Tinner, W., 2007. Pollen and plant macrofossils at Lac de Fully (2135 m a.s.l.): Holocene forest dynamics on a highland plateau in the Valais, Switzerland. Holocene 17, 1119-1127. http://dx.doi.org/10.1177/ 0959683607082552.

Gandouin, E., Franquet, E., 2002. Late Glacial and Holocene Chironomid Assemblages in Lac Long Inférieur (Southern France, 2090 m): Palaeoenvironmental and Palaeoclimatic Implications.

Gianotti, F., Forno, M.G., Ivy-Ochs, S., Kubik, P.W., 2008. New chronological and stratigraphical data on the Ivrea amphitheatre (Piedmont, NW Italy). Quat. Int. 190, 123-135. http://dx.doi.org/10.1016/j.quaint.2008.03.001.

Gidon, M., Monjuvent, G., 1969. Essai de coordination des formations quaternaires de la moyenne Durance et du haut Drac (Hautes-Alpes). Bull. Afeq 2, 145-161.

Giesecke, T., Bennett, K.D., Birks, H.J.B., Bjune, A.E., Bozilova, E., Feurdean, A., Finsinger, W., Froyd, C., Pokorný, P., Rösch, M., Seppä, H., Tonkov, S., Valsecchi, V., Wolters, S., 2011. The pace of Holocene vegetation change testing for synchronous developments. Quat. Sci. Rev. 30, 2805-2814. http:// dx.doi.org/10.1016/j.quascirev.2011.06.014.

Giguet-Covex, C., Arnaud, F., Poulenard, J., Disnar, J.-R., Delhon, C., Francus, P., David, F., Enters, D., Rey, P.-J., Delannoy, J.-J., 2011. Changes in erosion patterns during the Holocene in a currently treeless subalpine catchment inferred from lake sediment geochemistry (Lake Anterne, $2063 \mathrm{~m}$ a.s.l., NW French Alps): the role of climate and human activities. Holocene 21, 651-665. http://dx.doi.org/ $10.1177 / 0959683610391320$.

Giraudi, C., Frezzotti, M., 1997. Late Pleistocene glacial events in the Central Apennines, Italy. Quat. Res. 48, 280-290. http://dx.doi.org/10.1006/qres.1997.1928.

Goehring, B.M., Vacco, D.A., Alley, R.B., Schaefer, J.M., 2012. Holocene dynamics of the Rhone Glacier, Switzerland, deduced from ice flow models and cosmogenic nuclides. Earth Planet. Sci. Lett. 351-352, 27-35. http://dx.doi.org/10.1016/ j.epsl.2012.07.027.

Grimm, E.C., 1987. CONISS: a FORTRAN 77 program for stratigraphically constrained cluster analysis by the method of incremental sum of squares. Comput. Geosci. 13, 13-35. http://dx.doi.org/10.1016/0098-3004(87)90022-7. 
Guiter, F., 2003. Contribution pollen-analytique à l'histoire de la végétation au cours des derniers 100.000 ans dans la région d'Evian (Haute-Savoie, France): implications pour la chronologie du dernier glacier du Rhône (PhD thesis). AixMarseille Université III.

Guiter, F., Triganon, A., Andrieu-Ponel, V., Ponel, P., Hébrard, J.-P., Nicoud, G., De Beaulieu, J.-L., Brewer, S., Guibal, F., 2005. First evidence of "in situ" Eemian sediments on the high plateau of Evian (Northern Alps, France): implications for the chronology of the Last Glaciation. Quat. Sci. Rev. 24, 35-47. http:// dx.doi.org/10.1016/j.quascirev.2004.06.011.

Hannss, C., 1970. Les glaciers les plus méridionaux des Alpes. Observations de la morphologie glaciaire dans les Alpes Maritimes, versant italien. Rev. Géogr. alpine LVIII, 619-648.

Heiri, O., Millet, L., 2005. Reconstruction of Late Glacial summer temperatures from chironomid assemblages in Lac Lautrey (Jura, France). J. Quat. Sci. 20, 33-44. http://dx.doi.org/10.1002/jqs.895.

Heiri, O., Wick, L., van Leeuwen, J.F., van der Knaap, W.O., Lotter, A.F., 2003. Holocene tree immigration and the chironomid fauna of a small Swiss subalpine lake (Hinterburgsee, $1515 \mathrm{~m}$ asl). Palaeogeogr. Palaeoclimatol. Palaeoecol. 189, 35-53. http://dx.doi.org/10.1016/S0031-0182(02)00592-8.

Höfer, H., 1922. Die relative Lage der Firnlinie. Petermanns Geogr. 68, 57.

Hormes, A., Ivy-Ochs, S., Kubik, P.W., Ferreli, L., Maria Michetti, A., 2008. 10Be exposure ages of a rock avalanche and a late glacial moraine in Alta Valtellina, Italian Alps. Quat. Int. 190, 136-145. http://dx.doi.org/10.1016/ j.quaint.2007.06.036.

Ilyashuk, B., Gobet, E., Heiri, O., Lotter, A.F., van Leeuwen, J.F.N., van der Knaap, W.O., Ilyashuk, E., Oberli, F., Ammann, B., 2009. Lateglacial environmental and climatic changes at the Maloja Pass, Central Swiss Alps, as recorded by chironomids and pollen. Quat. Sci. Rev. 28, 1340-1353. http://dx.doi.org/10.1016/ j.quascirev.2009.01.007.

Ivy-Ochs, S., Kerschner, H., Reuther, A., Preusser, F., Heine, K., Maisch, M., Kubik, P.W., Schlüchter, C., 2009. Latest Pleistocene and Holocene glacier variations in the European Alps. Quat. Sci. Rev. 28, 2137-2149.

Ivy-Ochs, S., Kerschner, H., Reuther, A., Preusser, F., Heine, K., Maisch, M., Kubik, P.W., SchlÜchter, C., 2008. Chronology of the last glacial cycle in the European Alps. J. Quat. Sci. 23, 559-573. http://dx.doi.org/10.1002/jqs.1202.

Joerin, U.E., Nicolussi, K., Fischer, A., Stocker, T.F., Schlüchter, C., 2008. Holocene optimum events inferred from subglacial sediments at Tschierva Glacier, Eastern Swiss Alps. Quat. Sci. Rev. 27, 337-350. http://dx.doi.org/10.1016/ j.quascirev.2007.10.016.

Jorda, M., 1975. Les montagnes du Haut Verdon, Étude géomorphologique. Méditerranée 1, 37-58. http://dx.doi.org/10.3406/medit.1975.1585.

Jorda, M., 1976. La région du Lac d'Allos (Alpes de haute Provence), Carte géomorphologique Allos n 3-1/20.000 . Méditerranée 3, 49-62.

Jorda, M., 1980. Le glaciaire quaternaire des Alpes de Haute Provence. Revue Géographie alpine, Montagnes et Montagnards, Hommage à P. Veyret, pp. 183-194.

Jorda, M., 1983. L'évolution glaciaire d'altitude dans les Alpes françaises du Sud au cours des quinze derniers millénaires. Oscillations fini- et postglaciaires des glaciers. Formes glaciaires et périglaciaires. Balkema, Rotterdam, pp. 35-54.

Jorda, M., 1988. Modalités paléoclimatiques et chronologiques de la déglaciation würmienne dans les Alpes françaises du Sud (Bassin durancien et Alpes de Haute Provence). Bull. l'Assoc. Fr. l'étude Quat. 25, 111-122.

Jorda, M., de Beaulieu, J.-L., 1977. Tardiglaciaire et Postglaciaire des Alpes de HauteProvence. Le glaciaire de la Blanche, Trois évêchés. Bull. l'Assoc. fr. l'étude quat. 14, 3-15. http://dx.doi.org/10.3406/quate.1977.1307.

Jorda, M., Rosique, T., Évin, J., 2000. Données nouvelles sur l'âge du dernier maximum glaciaire dans les Alpes méridionales françaises. C. R. l'Acad. Sci. Ser IIA Earth Planet. Sci. 331, 187-193. http://dx.doi.org/10.1016/S1251-8050(00) 01408-7.

Jorda, M., Rosique, T., 1994. Le Tardiglaciaire des Alpes françaises du Sud: Rythme et modalités des changements bio-morphoclimatiques. Quaternaire 5, 141-149.

Juggins, S., 2012. C2 Version 1.5, User Guide. Software for Ecological and Palaeoecological Data Analysis and Visualisation. Newcastle University, UK, 77 pp.

Julian, M., 1980. Les Alpes franco-italiennes, Etude Geomorphologique. Aix-Marseille Université.

Julian, M., Anthony, E., 1996. Aspects of landslide activity in the Mercantour Massif and the French Riviera, southeastern France. Geomorphology 15, 275-289. http://dx.doi.org/10.1016/0169-555X(95)00075-G.

Kelly, M.A., Kubik, P.W., Von Blanckenburg, F., Schüchter, C., 2004. Surface exposure dating of the Great Aletsch Glacier Egesen moraine system, western Swiss Alps, using the cosmogenic nuclide 10Be. J. Quat. Sci. 19, 431-441. http://dx.doi.org/ $10.1002 /$ jqs. 854 .

Kerschner, H., Ivy-Ochs, S., 2008. Palaeoclimate from glaciers: examples from the Eastern Alps during the Alpine Lateglacial and early Holocene. Glob. Planet. Change 60, 58-71. http://dx.doi.org/10.1016/j.gloplacha.2006.07.034.

Klasen, N., Fiebig, M., Preusser, F., Reitner, J.M., Radtke, U., 2007. Luminescence dating of proglacial sediments from the Eastern Alps. Quat. Int. 164-165, 21-32. http://dx.doi.org/10.1016/j.quaint.2006.12.003.

Koinig, K.A., Shotyk, W., Lotter, A.F., Ohlendorf, C., Sturm, M., 2003. 9000 years of geochemical evolution of lithogenic major and trace elements in the sediment of an alpine lake - the role of climate, vegetation, and land-use history. J. Paleolimnol. 30, 307-320. http://dx.doi.org/10.1023/A:1026080712312.

Kharbouch, M., 2000. L'homme et la végétation dans la région du mont Bego (Tende, Alpes-Maritimes) depuis des millénaires. arocque, I., Finsinger, W., 2008. Late-glacial chironomid-based temperature reconstructions for Lago Piccolo di Avigliana in the southwestern Alps (Italy). Palaeogeogr. Palaeoclimatol. Palaeoecol. 257, 207-223. http://dx.doi.org/ 10.1016/j.palaeo.2007.10.021.

Lemdahl, G., 2000. Lateglacial and Early Holocene insect assemblages from sites at different altitudes in the Swiss Alps-implications on climate and environment. Palaeogeogr. Palaeoclimatol. Palaeoecol. 159, 293-312. http://dx.doi.org/ 10.1016/S0031-0182(00)00091-2.

Lischke, H., von Grafenstein, U., Ammann, B., 2013. Forest dynamics during the transition from the Oldest Dryas to the Bølling-Allerød at Gerzensee-a simulation study. Palaeogeogr. Palaeoclimatol. Palaeoecol. 391, 60-73. http:// dx.doi.org/10.1016/j.palaeo.2012.12.001.

Lopez-Garcia, P., Lopez-Saez, J.A., 2000. Le paysage et la phase épipaléolithiquemésolithique dans les prépyrénées aragonaises et le bassin moyen de l'Ebre à partir de l'analyse pollinique. Les derniers chasseurs-ceuilleurs de l'Europe occidentale (13000-5500 avant J.C.). Besançon, France, pp. 59-69.

Lotter, A., Birks, H.J., Eicher, U., Hofmann, W., Schwander, J., Wick, L., 2000. Younger Dryas and Allerød summer temperatures at Gerzensee (Switzerland) inferred from fossil pollen and cladoceran assemblages. Palaeogeogr. Palaeoclimatol. Palaeoecol. 159, 349-361. http://dx.doi.org/10.1016/S0031-0182(00)00093-6.

Lotter, A.F., 1999. Late-glacial and Holocene vegetation history and dynamics as shown by pollen and plant macrofossil analyses in annually laminated sediments from Soppensee, central Switzerland. Veg. Hist. Archaeobot. 8, 165-184. http://dx.doi.org/10.1007/BF02342718.

Lotter, A.F., Ammann, B., Sturm, M., 1992. Rates of change and chronological problems during the late-glacial period. Clim. Dyn. 6, 233-239. http:// dx.doi.org/10.1007/BF00193536.

Lotter, A.F., Birks, H.J.B., 2003. The Holocene palaeolimnology of Sägistalsee and its environmental history - a synthesis. J. Paleolimnol. 30, 333-342. http:// dx.doi.org/10.1023/A:1026091511403.

Magny, M., Aalbersberg, G., Bégeot, C., Benoit-Ruffaldi, P., Bossuet, G., Disnar, J.-R., Heiri, O., Laggoun-Defarge, F., Mazier, F., Millet, L., Peyron, O., Vannière, B., Walter-Simonnet, A.-V., 2006. Environmental and climatic changes in the Jura mountains (eastern France) during the Lateglacial-Holocene transition: a multi-proxy record from Lake Lautrey. Quat. Sci. Rev. 25, 414-445. http:// dx.doi.org/10.1016/j.quascirev.2005.02.005.

Magri, D., 2008. Patterns of post-glacial spread and the extent of glacial refugia of European beech (Fagus sylvatica). J. Biogeogr. 35, 450-463. http://dx.doi.org/ 10.1111/j.1365-2699.2007.01803.x.

Maisch, M., 1992. Die Gletscher Graubündens. In: Physische Geographie, vol. 33. Universität Zürich. Geographisches Institut, Zürich.

Mercuri, A.M., Mazzanti, M.B., Florenzano, A., Montecchi, M.C., Rattighieri, E., 2013. Olea, Juglans and Castanea: the OJC group as pollen evidence of the development of human-induced environments in the Italian peninsula. Quat. Int. http:// dx.doi.org/10.1016/j.quaint.2013.01.005.

Monegato, G., Ravazzi, C., Donegana, M., Pini, R., Calderoni, G., Wick, L., 2007. Evidence of a two-fold glacial advance during the last glacial maximum in the Tagliamento end moraine system (eastern Alps). Quat. Res. 68, 284-302. http:// dx.doi.org/10.1016/j.yqres.2007.07.002.

Moore, P.D., Webb, J.A., Collinson, M.E., 1991. Pollen Analysis. Blackwell Science Ltd.

Mourier, B., Poulenard, J., Carcaillet, C., Williamson, D., 2010. Soil evolution and subalpine ecosystem changes in the French Alps inferred from geochemical analysis of lacustrine sediments. J. Paleolimnol. 44, 571-587. http://dx.doi.org/ 10.1007/s10933-010-9438-0.

Muller, S.D., Nakagawa, T., De Beaulieu, J.-L., Court-Picon, M., Carcaillet, C., Miramont, C., Roiron, P., Boutterin, C., Ali, A.A., Bruneton, H., 2007. Post-glacial migration of silver fir (Abies alba Mill.) in the south-western Alps. J. Biogeogr. 34, 876-899. http://dx.doi.org/10.1111/j.1365-2699.2006.01665.x.

Nakagawa, T., 1998. Etudes palynologiques dans les Alpes Françaises centrales et méridionales: histoire de la végétation Tardiglaciaire et Holocène (PhD thesis) Aix-Marseille Université III.

Nicolussi, K., Kaufmann, M., Patzelt, G., van der Plicht, J., Thurner, A., 2005. Holocene tree-line variability in the Kauner Valley, Central Eastern Alps, indicated by dendrochronological analysis of living trees and subfossil logs. Veg. Hist. Archaeobot. 14, 221-234. http://dx.doi.org/10.1007/s00334-005-0013-y.

Ohlendorf, C., 1998. High Alpine Lake Sediments as Chronicles for Regional Glacier and Climate History in the Upper Engadine, Southeastern Switzerland (PhD thesis) $\mathrm{n}^{\circ} 12705 . \mathrm{ETH}$

Ortu, E., 2002. Reconstruction sur base pollinique de la dynamique de la végétation tardiglaciaire et holocène dans les Alpes Maritimes Italiennes (PhD thesis). AixMarseille Université III.

Ortu, E., David, F., Caramiello, R., 2005. Effet des paramètres locaux sur le développement de la végétation dans le Vallon de St. Anna di Vinadio (Alpes Maritimes; Italie). Ecoscience 12, 122-135. http://dx.doi.org/10.2980/i11956860-12-1-122.1.

Pallàs, R., Rodés, Á., Braucher, R., Carcaillet, J., Ortuño, M., Bordonau, J., Bourlès, D., Vilaplana, J.M., Masana, E., Santanach, P., 2006. Late Pleistocene and Holocene glaciation in the Pyrenees: a critical review and new evidence from $10 \mathrm{Be}$ exposure ages, south-central Pyrenees. Quat. Sci. Rev. 25, 2937-2963. http:// dx.doi.org/10.1016/j.quascirev.2006.04.004.

Petersen, J., Wilhelm, B., Revel, M., Rolland, Y., Crouzet, C., Arnaud, F., Brisset, E., Chaumillon, E., Magand, O., 2014. Sediments of Lake Vens (SW European Alps, France) record large-magnitude earthquake events. J. Paleolimnol. 51, 343-355. http://dx.doi.org/10.1007/s10933-013-9759-x. 
Peyron, O., Bégeot, C., Brewer, S., Heiri, O., Magny, M., Millet, L., Ruffaldi, P., Van Campo, E., Yu, G., 2005. Late-Glacial climatic changes in Eastern France (Lake Lautrey) from pollen, lake-levels, and chironomids. Quat. Res. 64, 197-211. http://dx.doi.org/10.1016/j.yqres.2005.01.006.

Ponel, P., Andrieu-Ponel, V., Parchoux, F., Juhasz, I., de Beaulieu, J.-L., 2001. Lateglacial and Holocene high-altitude environmental changes in Vallée des Merveilles (Alpes-Maritimes, France): insect evidence. J. Quat. Sci. 16, 795-812. http://dx.doi.org/10.1002/jqs.634.

Ponel, P., Court-Picon, M., Badura, M., Guiter, F., de Beaulieu, J.-L., Andrieu-Ponel, V., Djamali, M., Leydet, M., Gandouin, E., Buttler, A., 2011. Holocene history of Lac des Lauzons (2180 $\mathrm{m}$ a.s.l.), reconstructed from multiproxy analyses of Coleoptera, plant macroremains and pollen (Hautes-Alpes, France). Holocene 21, 565-582. http://dx.doi.org/10.1177/0959683610385725.

Preusser, F., SchlÜchter, C., Drescher-Schneider, R., Ivy-Ochs, S., Kelly, M., 2006. Comment on "First evidence of 'in-situ' Eemian sediments on the high plateau of Evian (Northern Alps, France): implications for the chronology of the Last Glaciation" by F. Guiter, A. Triganon, V. Andrieu-Ponel, P. Ponel, J.-P. Hébrard, G. Nicoud, J.-L. De Beaulieu, S. Brewer, F. Guibal. Quat. Sci. Rev. 25, 645-647. http:// dx.doi.org/10.1016/j.quascirev.2005.09.004.

Rasmussen, S.O., Seierstad, I.K., Andersen, K.K., Bigler, M., Dahl-Jensen, D., Johnsen, S.J., 2008. Synchronization of the NGRIP, GRIP, and GISP2 ice cores across MIS 2 and palaeoclimatic implications. Quat. Sci. Rev. 27, 18-28. http:// dx.doi.org/10.1016/j.quascirev.2007.01.016.

Ravazzi, C., Pini, R., Badino, F., De Amicis, M., Londeix, L., Reimer, P.J., 2014. The latest LGM culmination of the Garda Glacier (Italian Alps) and the onset of glacial termination. Age of glacial collapse and vegetation chronosequence. Quat. Sci. Rev. 105, 26-47. http://dx.doi.org/10.1016/j.quascirev.2014.09.014.

Reille, M., 1999. Pollen et spores d'Europe et d'Afrique du nord. Laboratoire de botanique historique et palynologie.

Reimer, P.J., Bard, E., Bayliss, A., Beck, J.W., Blackwell, P.G., Bronk Ramsey, C., Buck, C.E., Cheng, H., Edwards, R.L., Friedrich, M., Grootes, P.M., Guilderson, T.P., Haflidason, H., Hajdas, I., Hatté, C., Heaton, T.J., Hoffmann, D.L., Hogg, A.G., Hughen, K.A., Kaiser, K.F., Kromer, B., Manning, S.W., Niu, M., Reimer, R.W., Richards, D.A., Scott, E.M., Southon, J.R., Staff, R.A., Turney, C.S.M., van der Plicht, J., 2013. IntCal13 and Marine13 radiocarbon age calibration curves 0-50,000 years cal BP. Radiocarbon 55 (4), 1869-1887.

Reitner, J.M., 2007. Glacial dynamics at the beginning of Termination I in the Eastern Alps and their stratigraphic implications. Quat. Int. 164-165, 64-84. http:// dx.doi.org/10.1016/j.quaint.2006.12.016.

Ribolini, A., Chelli, A., Guglielmin, M., Pappalardo, M., 2007. Relationships between glacier and rock glacier in the Maritime Alps, Schiantala Valley, Italy. Quat. Res. 68, 353-363. http://dx.doi.org/10.1016/j.yqres.2007.08.004.

Richard, H., Bégeot, C., 2000. The Lateglacial injurassian massif: state and research perspectives. Quaternaire 11, 145-154. http://dx.doi.org/10.3406/ quate.2000.1663.

Richer, S., 2009. From Pollen to People: the Interaction between People and Their Environment in the Mid- to High- Altitudes of the Southern French Alps (PhD thesis). York University.

Rosique, T., 2004. La dernière phase glaciaire de la moyenne Durance (région de Gap à Sisteron): bilan des recherches, dernières conclusions chronologiques. In: Géosystèmes montagnards et méditerranéens, un mélange offert à Maurice Jorda. Méditerranée 1, pp. 25-35.

Schweizer, G., 1968a. Der Formenschatz des Spät- und Postglazials in den Hohen Seealpen. Aktualmorphologische Studien im Oberen Tinée. Z. Geomorphol. 6.

Schweizer, G., 1968b. Le tardiglaciaire et le niveau des neiges permanentes dans les hautes montagnes des Alpes-Maritimes. L'exemple du bassin supérieur de la Tinée. Méditerranée 9, 23-40. http://dx.doi.org/10.3406/medit.1968.1263.

Thevenon, F., Adatte, T., Spangenberg, J.E., Anselmetti, F.S., 2012. Elemental (C/N ratios) and isotopic ( $\delta 15 \mathrm{Norg}, \delta 13 \mathrm{Corg}$ ) compositions of sedimentary organic matter from a high-altitude mountain lake (Meidsee, $2661 \mathrm{~m}$ a.s.l., Switzerland): Implications for Lateglacial and Holocene Alpine landscape evolution. Holocene 22, 1135-1142. http://dx.doi.org/10.1177/ 0959683612441841.

Tiercelin, J.-J., 1977. Fronts glaciaires d'âge Würmien dans les environs du Poët, vallée de la Durance. Geol. Méditerr. IV, 307-312.

Tinner, W., Ammann, B., Germann, P., 1996. Treeline fluctuations recorded for 12,500 years by soil profiles, pollen, and plant macrofossils in the Central Swiss Alps. Arct. Alp. Res. 28, 131. http://dx.doi.org/10.2307/1551753.

Van der Knaap, W.O., van Leeuwen, J.F.N., Finsinger, W., Gobet, E., Pini, R., Schweizer, A., Valsecchi, V., Ammann, B., 2005. Migration and population expansion of Abies, Fagus, Picea, and Quercus since 15000 years in and across the Alps, based on pollen-percentage threshold values. Quat. Sci. Rev. 24, 645-680. http://dx.doi.org/10.1016/j.quascirev.2004.06.013.

Van Husen, D., 1997. LGM and Late-Glacial fluctuations in the eastern Alps. Quat. Int. 38/39, 109-118.

Vescovi, E., Ravazzi, C., Arpenti, E., Finsinger, W., Pini, R., Valsecchi, V., Wick, L., Ammann, B., Tinner, W., 2007. Interactions between climate and vegetation during the Lateglacial period as recorded by lake and mire sediment archives in Northern Italy and Southern Switzerland. Quat. Sci. Rev. 26, 1650-1669. http:// dx.doi.org/10.1016/j.quascirev.2007.03.005.

Wick, L., 2000. Vegetational response to climatic changes recorded in Swiss Late Glacial lake sediments. Palaeogeogr. Palaeoclimatol. Palaeoecol. 159, 231-250. http://dx.doi.org/10.1016/S0031-0182(00)00087-0.

Wohlfarth, B., Possnert, G., Skog, G., Holmquist, B., 1998. Pitfalls in the AMS radiocarbon-dating of terrestrial macrofossils. J. Quat. Sci. 13, 137-145.

Zohary, D., Hopf, M., 2000. Domestication of Plants in the Old World. Oxford University Press, New York. 